C/65-24

\title{
THE USE OF TRADITIONAL MEDIA FOR MODERNIZATION IN COMMUNIST CHINA
}

\author{
Alan P. L. Liu
}

RESEARCH PROGRAM ON PROBLEMS OF INTERNATIONAL COMMUNICATION AND SECURITY

CENTER FOR INTERNATIONAL STUDIES MASSACHUSETTS INSTITUTE OF TECHNOLOGY CAMBRIDGE - MASSACHUSETTS

OCTOBER, 1965 
$c / 65-24$

THE USE OF TRADITIONAL MEDIA FOR MODERNIZATION IN COMMUNIST CHINA

Alan $P_{0} I_{0}$ Liu

Research Proaram on Problems of International Communication and security

Center for International Studies Massachusetts Institute of Technology Cambridge, Massachusetts

$$
\text { October, } 1965
$$





\section{Introduction}

This is a study of traditional chinese media of communication under the Communist regime。*

We shall discuss three major traditional channels of communication: theater, story-tellina and ballad singind. since these are traditional media, they each have a history. But historical data are rare, especially on story-tellina and ballad sinqing. For evidence on how the Chinese communists have turned these media into weapons of Communist propaganda and nation buildina, we have used mainly Chinese Communist publications. We are interested in obtaining detailed statistical information on each of the three media. But only incomplete statistical information on opera is available and hardly any reliable statistics can be found on the other two media. We have practically exhausted all the major sources on this subject in Chinese which are publicly available abroad。

The research was sponsored by the Advanced Research Projects Agency of the Department of Defense (ARPA) under contract \#920F-9717 and monitored by the Air Force Office of Scientific Research (AFOSR) under contract AF $49(638)-1237$. 


\section{Table of Contents}

Introduction

Chapter

I Communication in Traditional China 1

II The Chinese Theater 16

III Drama Reform in Communist China 20

IV Story-Telling in China $\quad 47$

V Songs, Poems and Agitation 72

VI Poetry Recitals 82

VII Conclusion $\quad 86$

$\begin{array}{ll}\text { Bibliography } & 94\end{array}$ 
Communication in Traditional China

Although sinology in the west has a long history, its inclusion of sociology is a relatively recent development. Among the few studies on traditional Chinese social life, none deals with social communication specifically. It is against this background that this chapter is written.

Through a review of a few major village studies, which were almost all done in the late 1930's, we are able to draw a general picture of social communication in traditional china.

We can first identify two types of social communication in traditional China, administrative and entertainment. Administrative communication consisted of an official network and a local oral network below it. Entertainment was provided by professional theatrical performances, story-telling and ballad singing.

\section{Administrative Communication}

The main links in the official communication network were also the main divisions of the imperial bureaucracy in old China. The starting point of official communication was the capital. From there the official line of communication extended to provincial capitals and then to its termination point, the county seats. By termination we do not mean that official messages stopped at the county seat. Rather, we mean that from the county seat downward, official 
messages no longer traveled through bureaucratic channels, but through informal mouth-to-mouth channels, the local network. John K。 Fairbank has provided us with a picture of official or bureaucratic communication in traditional China: ${ }^{1}$

Official business over the far-flung Chinese empire was conducted as in all bureaucracies by a flow of documents of many kinds. In their special forms and designations these multifarious communications mirrored the elaborate proliferation of red tape。A governor addressed his imperial master in certain prescribed forms and addressed his subordinates in others. Every communication began with a clear indication of its nature as a document to a superior, an equal, or a subordinate. Similarly there were special forms for memorials submitted to the Emperor and edicts issued from him。 Each document also went through a certain procedure of preparation, transmission, and reception. Hundreds of thousands of brush-wielding scriveners were kept busy year in and year out transcribing, recording, and processing official communications. In the imperial archives in the Peking palace are more than one hundred different types of documents which were in common use.

The flow of paper work was maintained by an official post which reached to all corners of the empire but was limited to the transportation of official mail, official shipments (as of funds), and persons traveling on official business. This postal system was made up of some two thousand stations stretched out along five main and many subsidiary routes which ran into Manchuria, across Mongolia, westward to Turkestan and Tibet, southeastward through the coastal provinces, and southward through the interior of Central China. Couriers and travelers on these routes were provided with official tallies entitling them to the use of the transportation facilities, which in different areas might be horses, camels, donkeys, chairs (palanquins), or boats。 In time of crisis couriers could cover 250 miles a day。

Such speed was achieved by the use of horses in relays, a system which the Mongols had developed

Io John King Fairbank, The United States and China, New York, The Viking Press, 1958, pp。89-90。 
to cover the distances of Central Asia. In the early nineteenth century this pony express regularly transmitted messaces from Canton to Deking in less than three weeks and from Shanahai to Peking in one week。

The main characteristic that set official communications apart from those that reached below the county seat was the former's use and, indeed, monopoly of the printed media. Still, in the world of traditional Chinese officialdom bureaucratic written communication was often tempered by informal face-to-face contact among officials. Political cliques were common and these were face-to-face small groups. Their influence on the formal and riaid bureaucratic channel of communication was considerable.

In the formal structure of the traditional Chinese qovernment, the county seat was the lowest public office and hence the last link of the official communication ${ }^{2}$ From the county seat downward the official message was channeled through the informal mouth-to-mouth network of communication。

Administrative Communication at the Local Level

In order to describe local communication, we borrow the model of rural marketing structure in traditional China. The model was developed by Go William Skinner. ${ }^{3}$

The center of rural marketina was the market town. But there were different types of market towns in China, in terms of their size and social characteristics. Skinner classifies the Chinese

2. Fei Hsiao-tung, Hsianq-Tu Chunq-Kuo (Earthbound China), Shanqhai, Kwand Cha Se (Observer), 1949, p.46.

3. Go William Skinner, Marketing and Social Structure in Rural China," The Journal of Asian Studies, XXIV, 1, 1964, pp. 3-43. 
market towns into standard, intermediate and central market towns. The market town used for our model of social communication is the standard market town。 Skinner defines the standard market town as: 4

that type of rural market which met all the normal trade needs of the peasant household: what the household produced but did not consume was normally sold there, and what it consumed but did not produce was normally bought there. The standard market provided for the exchance of goods produced within the market's dependent area, but more importantly it was the starting point for the upward flow of agricultural products and craft items into hidher reaches of the marketing system, and also the termination of the downward flow of imported items destined for peasant consumption.

Skinner further finds that a majority of standard market towns and their outlying villages form a hexagonal shape. i standard market town was surrounded by six villages which also constituted the marketing area (Figure 1). Skinner notes that this mode $1^{5}$ calls for six major paths radiating out from the town。

These paths are at once the arteries and the veins of an economic system whose heart is the market in the town at its center. Alona these paths in the early morning hours of every market day, typically pass at least one out of every five adults living in a whole array of dependent villages。 In Tai-tou, the shantung village described by Martin Yang. "some member from almost every household in the village is in the town on market day," while in Lutsun, the Yunnan village studied by Fei and Chang, "at least one went from each household each market day."

The market town was the center for information exchange. From the market town regional news as well as official news was diffused to all the outlying villages through mouth-to-mouth

5. Ibid., p.6. Ibid. pp. 18-19.


Fiqure 1: Skinner's Model of the Chinese Standard Marketing Area. 6

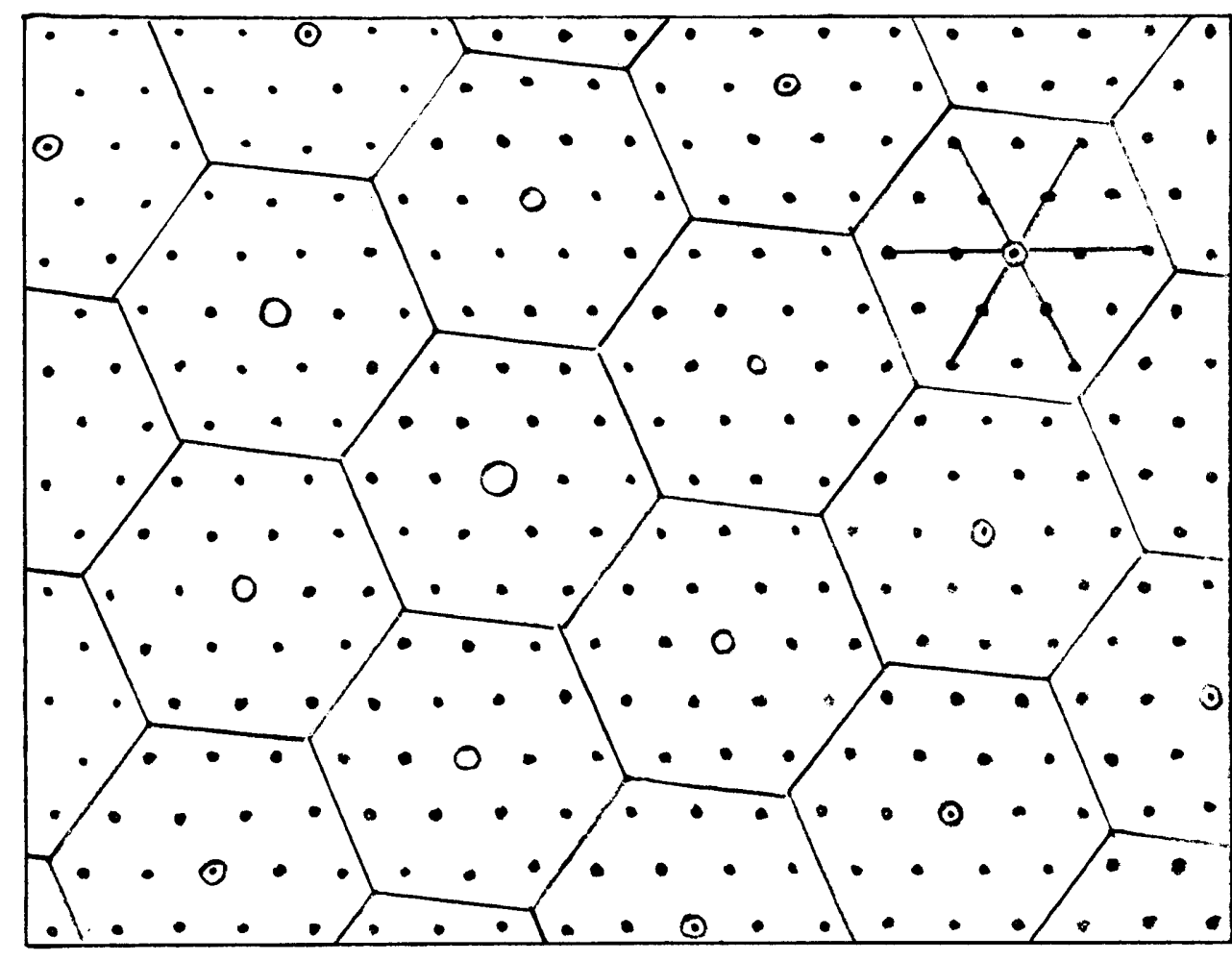

KEY :

- Village

O Standard Market Town

- Other Market Town of Variable Status

Limits of Standard Marketing Area

6. Ibid., p. 19. 
tramsrission. That this is a frequent pattern is attested by

Matin Yand's description of the village of Taitou in shantund province : ${ }^{7}$

The market town provides opportunities for farmers from different villages to meet one another, and is in fact one of the few places where they can meet. Chinese farmers alvays have friends and relatives in other villaces and these neetinas in the market take the place of visits, which would be more expensive. Then the farmers return home they report to the whole family what they have seen and heard and, in this way, people are kept informed about one another.

The standard market town was not the county seat. ${ }^{8}$ Hence for an official communication to reach peasants, it had to go to the market town first and then be disseminated through mouth-to-mouth channels. Thus Martin Yang writes of Taitou village, Shantung province : 9

$\lambda$ aroup of soparated villacos may ampear isolated from the larcer rural community, but it is easy to see in the market town on market day, how their integration is accomplished. When the local government proposes some desirable but not mandatory proqram, leaders of all villages of the area will be called to the market town to confer with the authorities and offer their opinions. Back in the villages the official leaders co to the important laymen leaders and the villacers to tell them what has happened in the market town. Villagers are not in a position to propose anything definite, but they talk the matter over among themselves. On the following market days, the official leaders find out from each other the opinions of their respective villages regarding the particular matter. The laymen leaders

\footnotetext{
7. Martin Yang, $\bar{A}$ Chinese Village: Taitou, Shantung Province, New York, Columbia University Press, 1965 (paperback edition), p. 193.

8. Skinner, op. cit., p. 9.

9. Martin Yang, op. cit., p. 193.
} 
do the same thing and sometimes meet with the official leaders for a general discussion. After two or three weeks, when the case has been discussed again and aqain, the local authority summons the leaders of the villages and important men of the local area to the market town for a final decision. Then every village starts to make plans for the program.

Let us now look more intensively into the dynamics of local communication. A more microscopic view of this immediately brings into focus the role of the tea house in the market town as the real center of information dissemination and the role of rural gentry as the single most vital transmission belt of communication from the officials to the masses.

The importance of the tea house as a community center of social life has been noted in several studies on Chinese villages. Martin Yang describes the tea houses in the market town of Isinanchen, Shantung province $:^{10}$

Most of the leaders in a Chinese rural community have leisure time, which they are apt to spend in the wine shops $c=$ the teahouses in the market town. They talk or arque in the stores on current affairs or historical events and discuss community problems. Many community programs, good and bad, come out of such informal gatherings and many problems have been solved, wisely or not, in these discussions...

- . Teahouses and wine shops generate rumors which are widely spread. There is an old saying that statesmen should listen to the talk in these hidden corners. Public opinion and social attitudes take form in them and there are numerous historical tales of Chinese officials who visited them in disquise in order to discover what the common man was sayina about current affairs. It is well known that the farmer does not have much to say at home but is a good talker whenever he

T0. IbIa., ppo 193-194. 
finds himself in the market tow and sits with his

fellow villagers in the teahouse.

In his study of the villade of Kao Yao, Yunnan province,

Cornelius Oscood describes how the tea house was used by the village head to disseminate news $:^{11}$

\begin{abstract}
... Occasionally he (village head) called public meetinas to discuss such matters as how reguired public works should be shared or who should be enrolled in the army. It was the effective way of resolving community problems, the news of which, like most other news, was first disseminated through the teahouses....
\end{abstract}

Then osgood describes how the tea house was a center of village social life: ${ }^{12}$

...the most common social pleasure in Kao Yao
appeared to be derived from conversation and
gossip. For males, this activity centered in
the teahouses. Those who worked took their
rest here, and those who did not, spent most of
the day in them. There was no other place to
go. only after supper did families sometimes
visit each other's homes. The teahouses func-
tioned as men's clubs, in a sense, and a vil-
lager could sit in one without spending a copper
if he wished. Most Kao Xao residents liked to
talk... The chief topic of conversation was
stated to be prognostications about the weather,
a subject which was reasonable enough among
farmers. This was followed, as should be ex-
pected, by conversations about the condition of
the rice fields. These questions satisfied, a
man might boast of the quality of his crops....
general news, especially that pertaining to
nearby villaces, but also of such tragedies
as destructive floods and the impinging war.
only educated men told stories, and these were
very rare in the teahouses or homes in Kao Yao....

II. Cornelius osgood, Village Life in Old China, New York, The Ronald Press Company, 1963, p. II8.

12. Ibid., p. 229. 
The visits to tea houses by Chinese peasants were regular and frequent. In Kao Yao, Osgood observes: "There was no special time for rest during the day, but men often went to a tea house after dinner。"13 In the market town of Kao-tien-tzu, Szechwan province, Skinner notes: ${ }^{14}$

...The peasant in Kao-tien-tzu's marketing community had, by the age of fifty, attended his standard market more than three thousand times. He had, at least one thousand times on the average, been jammed into a small area along one street with the same male representative of every other household in that community. He made purchases from peasant vendors whose homes lay in all directions from the town, and more to the point, he socialized in the teahouses with fellow peasants from village communities far removed from his own. Nor was the peasant alone in this, for in Kao-tien-tzu there was a teahouse for everyone, and few persons who went to market failed to spend at least an hour in one or two. Codes of hospitality and sociability operated to bring any community member who entered the door quickly to a table as somebody's quest. Inevitably an hour in the tea house enlarged a man's circle of acquaintances and deepened his social knowledge of other parts of the community.

Eventually tea houses became an indispensable part of the social life of Chinese peasants. Martin Yana tells about a Chinese social worker who set up a tea house in his village so that the villagers would not have to go all the way to the tea house in the market town. But few villagers visited the new tea house. Then the social worker moved the tea house to the center of the village and improved its customer service. But still few villagers came to visit. Most of them continued to go to the tea 
nowse in the market tom. The social worker finally found the reason: 15

...They (the social worker and others) learned that many of the farmers who go to drink tea every day at the market town do so because they feel they must. Everybody has followed the custom for generations and they dare not break it. Many can ill afford it, but should they fail to present themselves for a few days runnind in the market-town teahouse, they would immediately become the object of rumors and their financial credit would be suspected by everybody in the community. The market-town stores would refuse to delay the payment of debts or deny any extension of credit. Their friends would avoid them or greet them coldly. Finally, they would be in danger of bankruptcy. Therefore, in order to maintain their social prestice or to hide their economic weakness, they have to go to the market-town teahouse every day. This is why a villager may sometimes co to market town when he has no business there. He is seen sometimes just wandering in the town or going to and from the market town with an empty basket.

So much for the role of the tea house as an information diffusion center in traditional China. But how was information actually disseminated? Information from the county seat downward was channeled throuah mouth-to-mouth, but whose mouth? We have already quoted Martin Yand's mention of official leaders conferring with "laymen leaders" in a community。 This phenomenon has been noted by other studies on Chinese villages, C. K. Yang, in his study of a village in Kwangtung province, writes: ${ }^{16}$

The village had two persons of the old-style dentry backqround still livina. One had moved to the city some decades ago, but one still lived in the village during our investidation. He was Lee Yina, a man in

15. Tartin Yang, op. cit., p. 196.

16. C. K. Yang, A Chinese Villace in Early communist Transition, Cambridge, The M.I.T.Press, 1959, pp. I12-II3. 
his mid-sixties, who had a hsiu tsai degree, the lowest degree granted by the imperial examinations. Up to about three decades aqo, it was he and several others like him who went to the county magistrate ${ }^{\prime} s$ office to negotiate business concerning the community of individuals in the village. Traditional respect for scholarship and the accessibility to qovernment officials gave him a position and power in the villace, and few decisions on community affairs were made without consulting him。

The power of the village aentry referred to as "laymen

leaders" in Martin Yang ${ }^{\circ} s$ study of Taitou is described as follows : 17

The laymen leaders remain in the background, but their role is so important that without their advice and support the chwang-chang (village head) and his assistant are unable to accomplish anything. The village gentry are also heads of the chief clans or families. If they object to a program, or even if they merely take a neqative attitude, the administration faces an impasse. Laymen leaders do not, as a rule, deal with the government directly. Sometimes the district leader or the county government invites them to a conference to hear their opinions reaarding a certain case; not infrequently their advice influences qovernmental policy. In the old days there were various ways of determining public opinion in the countryside, but as a rule public opinion was created not by the small farmers but by the rural gentry and clan heads. The local officials were often ordered by the central government to listen to these laymen leaders, who thus played an inconspicuous but important role in local politics. In the written history of a county there can be found many pages devoted to the biographies of thousands of rural leaders which have been recorded carefully throuch hundreds of generations。 It is a wellrecoanized fact that a areat part of local history was made by them。

Thus all evidence points to the fact that the village gentry was the strategic link or intermediary between the masses and the 17. Martin Yang, opocit。 pp。184-185。 
officials. They were the traditional comberoarts of today's

"opinion leaders."

The most important qualification of a villace centry was his knowledae of the people. Sometimes the extensiveness of a village gentry's knowledge of his people is rather surprising. Skinner reports that in the market town of Kao-tien-tzu, Szechwan province, there were 2,500 households in $1949-1950$ but $^{18}$

... Did the average peasant even recoonize much less know the members of so many households? If Mr. Lin, the 45-year-old peasant with whom I lived, may be considered at all typical, then the answer is yes. For Mr. Iin had a nodding acquaintance with almost every adult in all parts of the marketing system. He could, moreover, identify and describe the community's leading elite families, in no matter which of the dispersed villages they lived. He knew details about peasant families on the other side of the market town which most Americans would not know--and would not care to know--about their next-door neighbors. Mr. Lin's social knowledge of kao-tien-tzu's marketing community was more impressive, perhaps, than that of the acricultural laborer who shared his compound or the transport coolie who carted his tangerines to market, but it paled by comparison with the informed social wisdom of any leisured gentleman among the community local elite. The long-robed landiord might nod to only a favored few, but he recognized everyone he passed on the way to market and appeared to carry in his head a full cossier on each.

Descending further from the gentry, the lowest link of regional communications was the clan leaders. Thus C. K. Yanq writes: "The clan had a strategic position in the maintenance of peace and order in the village..."19 The power relationship within a Chinese clan has been studied by a few scholars but here we do not wish to pursue 18. Skinner, op. cit.. p. 35; the underlines are this writer's. 19. C. K. Yang, op.cit., p. 109. 
it. It is sufficient for us to mention that next to the gentry the clan leaders mediated part of the communication diffused from the magistrate in the county seat and mediated first by the gentry. We can now see that however segmental these networks were, the official and regional networks were still linked by intermediaries. Geographically, the connection between the bureaucracy and peasantry was performed by the market town. Looked at from the human and social angle, we find that the connection between the elite and the masses was performed by the gentry。

But this fact of the existence of linkace between segmental networks of communication should not blind us to the dominant characteristics of these two networks. Most of the time the official and regional networks operated independently of each other。 The gap between the elite served by the bureaucratic communication network and the masses served by mouth-to-mouth channels was wide throughout Chinese history.

Entertainment Communication in Traditional China

The entertainment communication network, which consisted of professional story-tellers, theatrical troupes and blind singers, belonged to no particular social class in traditional China. They appealed to all social strata. They were mobile. They served vertically as a ladder connecting the elite and the masses and horizontally as a bridge among people of all localities. They selectively interpreted and transmitted the literate culture of the elite to the illiterate masses. They performed in the magistic imperial court and also in crude market town tea houses. 
Their content mixed the didactic literature of the elite and the human-interest stories of folk tales. Their messages were highly redundant in that they repeated the same stories quite often but each time they threw in new human-interest anecdotes. Thus their messages were consistently reinforced (redundancy) and yet still held their audience by novelty (anecdote). This plus their use of folk language accounted for their persistent popularity and survival throughout the long Chinese history.

Moreover they even survived the impact of Westernization in recent times. Story-telling, theatrical performances and folk singing when transmitted through radio or television reach many people and have won wide popularity. Such a system of indigenous mass communication is certainly an important social capital for any new government in China that is committed to the task of modernizing the country.

However, under the Nationalist qovernment, no effort was made to capitalize on these old media for political or economic purposes. Neither was there any effort on the part of the government to vitalize these media for their own sake. This situation underwent a radical change after the Chinese Communists took over the Chinese mainland in 1949. The new Communist regime is bent on politicizing every sphere of Chinese social life, especially folk media, for the benefit of the reqime's plan of economic development and social control.

This report is about the Communist Chinese effort to turn these traditional entertainment channels into an instrument of moderniza- 
tion. We are using the word "modernization" in its broadest sense, including ideological as well as economic transformation of the country.

Now we shall examine the transformation of three major traditional media: the Chinese theater, story-telling and ballad singing and one minor medium--poetry recitind. Let us begin with the theater. 
II

The Chinese Theater

From the past

The exact date of birth of the Chinese drama is unknown. Various dates are suggested, and they cover a period of more than 25 centuries.

References to dances and sond were found as early as the Chou Dynasty (1122-314 B.C.) and through the Tang Dynasty (618907 A.D.). Yet it was not until the Yuan Dynasty (1277-1368 A.D.) that the history of Chinese drama was recorded, and uninterrupted references exist since then. 20

Since Chinese drama combines sinqing and acting, it has often been referred to as Chinese opera. There are about one hundred styles in the Chinese opera. 21

All local operas in China had their origin in the countryside. This may have been because China is essentially an aqricultural society. "The early operas were rather primitive, with simple plots, few characters, more singina than dialocue... The early operas are chrecterizod by their closeness to real life: the themes deal with family relationships and love stories, while the characters presented are all types familiar to the peasants in their 20. Cecillia S. L. Zung, Secrets of Chinese Drama, Shanghai, Kelly and Walsh, Ltd. 1937, po. 59-60.

21. Chen Lin-jui, "A Popular Folk Drama," China Reconstructs, Peking, No. 6, 1952, p. 23. 
daily life." 22

As opera moved to the towns, a process of evolution took place. Themes became more varied. Historical events were sung and acted. And operas began to attract the attention of the imperial court. Well-known performers were called to play before the emperors, and plays considered hostile to the regime were banned.

Amona the Chinese operas, perhaps the Peking Opera is the most popular. However, the name "Peking" does not mean that the opera oriainated in Peking. It actually originated in Anhwei province. The Peking Opera differs from local operas in that it uses Mandarin as its lanquage and has absorbed many other tunes from local operas. Local operas use local dialects.

Plots in all Chinese operas are usually simple but the subjects are numerous. While the most popular plays feature the history of the country, others include such subjects as filial piety; the exaltation of learning; vices and official corruption; and the evil doings of some religious persons such as monks. The use of dialect in local operas facilitates comprehension among the viewers. Yet languace is not very cructa. in understandina a local opera in China. For the stage action and characters are so prescribed by tradition and so familiar from frequent repetition that lanquage really does not matter very much. In addition, common symbols are used in chinese operas. For example, the actors

22. Ma Yen-isiang, "A Brief Introduction to Peking Opera," in The Fisherman's Revenge, Peking, Foreign Language Press, 1956. pp. 3-4. 
have their faces painted and the colors have definite meanings. A red face suggests that the man is loyal and brave, a white face that he is crafty, a black face denotes resolution and tubbornness, and a blue or green face a hot and unaovernable temper. 23

To facilitate still further understandina by a largely illiterate audience, the characters as well as the names of the actors are announced by the program. "The entrance of an important player is, at times, followed by a self introduction in which he talks of the person he is to present; sometimes he will recount ; detail his family history, why he appears, where he is from, and what he desires to accomplish during the entire period of the play; he may even repeat certain of these speeches upon a sccond or a third entrance..."24

The adherence in the repertoire of Chinese opera to the tradition of reliqious and moralistic teaching, and the playwright's reiteration of historical events and personaces as dramatic material operate jointly as an educational medium in every part of the country to which the drama penetrates.

Even in traditional China, dramatic troupes existed in many parts of the country. Within their own geoqraphical confines, the troupes traveled extensively. During the spring and autumn, the Chinese peasants offered pageants and festivals. This was also the popular time for drama presentation. A temporary stade was set up in the field and crowds gathered around the stage. Such a spectacle miaht be financed by the rich man of the village or by a whole com23. Kate Buss, Studies in the Chinese Drama, New York, Jonathan Cape \& Harrison Smith, 1922, D. 48.

24. Ibid., pp. 57-58. 
munity. There were also River and Canal Troupes (Kiang Hu Pei) who lived on boats and used their floating domicile as a stage while the audience athered around the river bank. 25

The actor was the troubadour of traditional China. He carried news and entertainment to millions of peasants who had no other association with cities than that which was brought to them by the traveling players.

Yet the actors and playwrights were socially alienated. The Chinese lumped all dramatic artists together and named them "Hsi Tse" ("entertainer"), which had a derogatory implication. Kate Buss describes a typical Chinese actor: 26

Usually deriving from low birth and inheriting the position of a social outcast which developed for actors during the Mongol (Yuan) Dynasty, he is cut off from other society than that of theater people. Until recently the descendants of an actor, to the third generation, were forbidden to compete in the public examinations which offer to the poor man in China the unique opportunity to acquire wealth and influence.

Largely due to the low social status of dramatists, playwriting did not develop as a noble profession in China. After the Yuan Dynasty, the Chinese opera, especially Peking opera, did not develop any further.

25. Ibid., D.90.

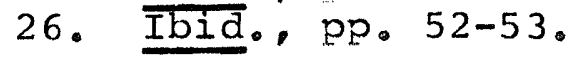


Drama Reform in Communist China

Structural Reform

When the Chinese Communists took over political power on the mainland in 1949, they started to turn Chinese drama into a modernizing and communizing weapon. In their two decades in the hinterland of China before they came to power, the Chinese Communists witnessed the power of this medium in influencing the isolated and illiterate peasants.

While still in Yenan, Mao was already uraing the Party's literary workers to "pay special attention to the small theatrical troupes in the army and in the villaces." 27

Yet in the initial years of the Communist rule on the mainland, only vague statements were issued about theatrical reform. The local cadres were instructed to ban those plays that had superstitious, feudal or anti-proletariat themes. The interpretation of these terms was left to the local cadres. Meanwhile the Party also urged playwrights to produce new plays to praise the Party, the dovernment and socialism.

As a result of these ambiguous instructions, a chaotic situation arose. In some areas, the local cadres forbade the showing of traditional drama of any kind. The reason given was that "all 27. Mao Tse-tung Hsun Chi (Selected Norks of Mao Tse-tuna), Peking, 
traditional dramas are superstitious and feudalistic."28 other cadres would give the local troupes a free hand because "the people like it。" 29

In response to that situation, the Opera Reform Bureau of the Ministry of Cultural Affairs in July, 1950, appointed an advisory committee consistina of 43 famous opera performers and dramatists and charged it with the responsibility of making recommendations on opera reform policy in general. 30

On November 27, 1950, the Ministry of Cultural Affairs convened a National Conference on Opera Reform. It was attended by more than 200 opera reform cadres and representatives of the dramatic profession from 47 provinces and municipalities. The conference echoed the regime's policy of utilizing traditional Chinese opera for political propaganda but recommended that henceforth the final decision on banning any play should be reserved to the Ministry of Cultural Affairs。 31

On May 4, 1951, the Government Administrative Council issued the following directive on opera reform: ${ }^{32}$

Operas which promote propaganda for antiaggression, anti-oppression, love-motherland, love-freedom, love-labor, righteousness and good nature of the people should be encouraged and promoted. On the other hand, those that advocate feudalistic morality, cruelty, horror,

28. Chao Chi-yang," on the Reform of Drama and Sond and Reform of Dramatists" Thought," in Wen-Yi Pao (Literary Gazette). Vol. 1, No. 11, 1950, p. 20.

29. Loc。 cit。

30. FrankIin $W$. Houn, To Change a Nation, New York, The Free Press, 1961, p. 184.

31. Loc. cit.

32. Jen-Min Jih-Pao (People's Daily), May 7, 1951. 
obscenity and which ridicule or insult the

laborers should be banned.

Shortly after that the Chinese Opera Research Institute was set up under the Ministry of Cultural Affairs to systematize the reform of operas. In the major cities of China research institutes of the same kind were set up to study the reform of local operas. While research was going on, new operas and old ones that needed a minimum of revision had to be produced for current use. To insure the correctness of these works, the government appointed editors to the research institutes. New plays were written jointly by old olaywrights and new "literary workers" sent by the qovernment.

In October, 1952, a convention yas held in Peking to examine the result of a year's opera reform work. It was attended by some 1,800 persons, and 23 types of operas were shown at the convention. 33

As a result of this a new set of requlations on conra reform was promulgated on December 26, 1952. State control of theatrical troupes was tiahtened. Amona the items of requlation vere the following:

1. All the state-controlled troupes must draw up quarterly or semi-annual performance schedules and submit them for approval to the local authorities in charge of cultural affairs. Once the schedules are approved, no chances are allowed.

2. The state-controlled opera troupes must spend at least six months every year aiving public performances in theaters and two or three months on mobile shows in factories, villaqes and army units.

33. Wen-Yi Pao (Iiterary Cazette), No. 22, 1952, p. 6. 
3. All the private theatrical troupes must reqister with the authorities in charge of cultural affairs above county government* and then submit application for approval of giving performances to provincial or municipal authorities in charge of cultural affairs.34

This, then, was the first wave of drama reform. While the above set of regulations seems to deal with organizational matters, the 1952 convention on drama reform also set the policy of thematic reform, summed up in the slogan of "Letting a Hundred Flowers Bloom and weeding through the old to Let the New Emerge."**

This means that the old were to be censored in the light of Communist doctrine and that new Party line drama was to be vigorously promoted.

Thematic Reform and Its Problems

However, when the Communists tried to implement the policy of "weeding through the old to let the new emerge," they encountered numerous problems. The main one was what part of the old should be discarded. There was a debate in the Party, continued now among Chinese intellectuals on the problem of Westernization or modernization of the Chinese culture. Almost every Chinese admits that there are weaknesses in the traditional culture and that it must be changed to pave the way for the modern ones. But every Chinese also has unquestioning faith that there are "virtues" in the traditional 34. Wen-Yi Pao (Literary Gazette), No.1, 1953, p.6。

* This means the Cultural Bureaus of either the provincial or municipal governments which are the immediate superiors of any county government in China.

** Another English translation of this slogan is "Something New Out of the old。" 
culture that should be preserved. Indeed, the virtues ought to be promoted. Yet when pressed to articulate what precisely these traditional "virtues" are, cven the most articulate chinese has difficulties. The Communists face the same dilemma in their drama reform。 The Communist Party claimed that the traditional Chinese drama was the product of the "feudal past," but it also declared that the Chinese drama is a fine legacy of the nation's culture. As self-styled rejuvenator of the Chinese nation, the Chinese Communist Party intended to inherit this legacy and, furthermore, bring this drama back to life.

But questions popped up as the Party-line dramatists leafed through the several thousand traditional plays. For example: 35

1. "Is drama reform merely 'surface dusting' or 'face cleaning'?"

As regards the method of drama reform, some comrades believed that "...on the basis of our predecessors, we should prodress steadily, step by step." They said that this was a "...universally practical method and a normal law suited for the development of plays and songs." They went on to say that "...on the stage of the old era, there were those classical plays which possessed rich democratic characteristics, which were covered with much dust, and which became dull, or twisted or intermixed with some of the dregs. All we are required to do is to clean off the dust, eliminate the dregs, and rectify the twisted parts, and then these richly democratic classical plays would exert the brilliance of socialist art."

... Some comrades disagreed. They said that "...the development of art is a new revolution, and it is different from the old art in its essential nature..."

35. All these excerpts of debates are from one lengthy article in Kuang Ming Jih Pao (Kuang Mina Daily), September 9, 1963. 
2. The question of morals in the plays. For generations, the teaching of loyalty, filial piety, fidelity and righteousness has been the main theme in traditional Chinese plays, designed to diffuse a popular culture over the land. Now the Communists asked themselves whether these old morals were compatible with Communist doctrine.

3. The question of plays involving crime and sex。 one dramatist said that such plays "are not only detrimental to a certain class, but harmful to the whole society..." and that "accordingly, every society must reject these plays." Others claimed that these plays were "reflections of that reactionary, backward and corrupted class life and should be shown to the people to expose the life of the reactionary class."

While these debates went on, the tightening of organizational and ideological control had already produced a crippling effect. Most of the old playwrights did not dare to write any more until the Party's position was clarified. Veteran actors stopped performing because their old roles were considered undesirable under the new regulations. In the meantime, local party cadres continued to interfere with performances, despite the Party authority's formal prohibition of such conduct.

Alarmed by the stalemate, the Party initiated a limited "thaw" in 1956. The Ministry of Culture called a National Conference of Drama Workers in that year and proposed reconsideration of traditional plays to enrich the repertoire. Then an unexpected though quite natural problem arose. This was the problem of "ghosts" and 
"fairies" in the plays. The majority of traditional Chinese plays contain these imaginary characters. The Chinese Communists had long been condemning the belief in ghosts as superstition. Now the party was in a dilemma. If it let ghost plays be shown, then it would have contradicted its previous stand. If the Party had banned those plays with ghosts, then the majority of traditional plays would have been withdrawn. Then the "thaw" would not only be meaningless but even lead to a deeper freeze. Furthermore, ghost plays are very popular among the people. "The people always sit in the theater and enjoy ancient plays with ghosts in them." 36 so, to ban ghost plays means to deprive the party of an efficient mass medium.

To solve this dilemma, some Communist dramatists proposed that "ghosts with rebellious and folk qualities should be permitted to appear on stage." Thus for a while, the government compromised its doctrine for the sake of breaking the stalemate in the Chinese theater.

However, "weeding through the old" is but one part of the Communist drama reform. The other part is to create new Communist plays using traditional techniques. This task of creating new Chinese opera on the model of the old was "more difficult than releasing old plays. This is a type of creative work. There are many regulations and restrictions on this. Furthermore, we have to overcome 'four fears.' They are: fear of the immaturity of the new play, fear of the lack of agreement between the substance 36. Jen-Min Jih-Pao (People's Daily), October 3, 1956. 
and the form, fear of failure and fear of audience dislike of the new play。" 37

In 1958, amidst the nationwide campaian of the Great Leap Forward, the Communist Party initiated a second wave of drama reform. In June, 1958, the Ministry of Culture convened a symposium on Dramatic Depiction of Modern Life. The Party's Deputy Minister of Propaganda, Chou Yang, said in the symposium: 38

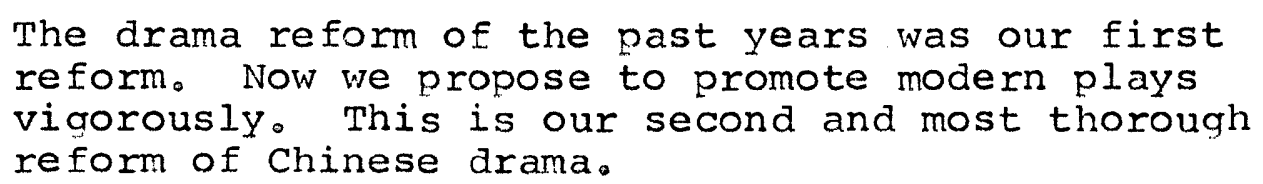

Chou Yang went on to say that violence had been done to traditional drama in the past years, "which destroyed many good things in our traditional art。" But he did not specify how the old had been violently dealt with and what "good things" in the traditional art had been destroyed. It seemed to be rather a ritualistic declaration that the Communist Party was not destroying the traditional art although the symposium was devoted to turning out more modern plays。

In 1958, the Communists did produce a modern Chinese opera using old techniques. This was the White-Haired Girl。 It was originally a crude propagandistic play shown in the countryside during the violelt land reform in the early 50's. The story is about a peasant girl named Yand Hsi-erh. Her father was driven to suicide by a landlord. The landlord then seduced and debauched the bereft daughter. She escaped to a hidden cave in a hill and 37. Hsi Chu Pao (Drama Gazette), No. 2, 1958, p. 5. 38. Jen-Min Jih-Pao (Teoples Daily), Auqust 7, 1958. 
gave birth to the landlord's child. As a result of her sorrow and hardship, her once lovely black hair turned white. She kept herself and her child alive by sneaking back to the village at night and taking the food offerings left on the altar of the local temple. The villagers thought her to be a fairy. They called her "the white-haired fairy" and kept on leaving food for her. Then the Communists came and unraveled the mystery. A mass trial of the landlord was held and the landlord was sentenced to death. Whereby the villagers sang: "We who have long suffered begin a new life today."

In this opera of the White-Haired Girl, the fancy traditional costumes were replaced by ragged peasant clothes, Red Army uniforms, rifles, etc. There was no more traditional facial make-up. New stage settings were used and a lighting arrangement was adopted. The dream of the ardent Party reformers was realized. But the real problem was: Did it work?

The answer: it did not. The "four fears" mentioned previously were only too real. The most obvious failure was the disconnection of substance and form. As we mentioned earlier, the White-Haired Girl used modern costumes. But it used traditional music for Peking opera and the actors sang in the traditional way. The traditional way was to match gestures, a crucial feature in the opera, with singing. Gestures must also be matched with costumes. Now with the disappearance of traditional costume, the music and gesture had lost their objectives. As a result, the White-Haired Girl became a masterpiece of incongruence. 
Thus in 1959, the Party had to compromise its plan once more. A new policy slogan was announced: "Walking on Two Legs." Chou Yang gives a definition of this slogan: 39

Peking Opera should continue to leap forward in its portrayal of modern life. Our task of rearranging and revising the excellent plays of the past should also continue to leap forward. From now on, we should encourage the creation of new plays to depict modern life. However, we should not expect too much. In the meantime, we should carry on our task in selecting, revising and rearranging the best numbers from the traditional repertoire. In short, we must do everythina possible to enrich and promote this stage art....

This did not bring any great improvement in the situation. One Western writer noted that the modern plays using old techniques that were produced in the period of 1958-1959 were apparently neither impressive in quality nor numerous in quantity. "As a propaganda device, so far these new numbers have not been shown anywhere outside mainland China." 40

In mid-1963, we again heard rumblind in the Communist drama circle. The third wave of drama reform was in the making. First, a decision was made concerning the ghost plays. Henceforth, all ghost plays would be banned. In the nation's chief literary journal, Wen-Yi Pao (Literary Gazette), the renowned playwright Chao Hsun writes: 41

A play is shown for the audience. What is harmful and what is beneficial must be judged according to the effect on the masses... The laboring people of

39. Hsi Chu Yen Chiu (Study of Drama), No. 4, 1959, p. 151. 40. Richard F. S. Yang, The Reform of Peking Opera under the Communists," The China Quarterly, July-September 1962 , p. 139.

41. Cited in Kuang Ming Jih Pao (Kuang Ming Daily), September 10, 1963. 
today, compared with those before the liberation, have generally elevated their ideological awareness and cultural level. However, the remnants of old consciousness and old habits still remain, and they are still a burden on the people's spirit, and superstition is one of them...To be entirely free of such mental confinement, long term education and struggle are required. Under this condition, what will be the effect of showing "ghost plays" on stage? Apparently, it will only promote the negative effect of superstition... and superstition will hamper the people from accepting the socialist and Communist ideologies, cause them to yield to destiny, and disbelieve that the laboring people can use their own two hands to reform society and the world... It will also furnish the counterrevolutionary elements with openings....

Finally, at the beginning of 1964 , a third wave of drama reform was started. A grand festival of modern opera using old Peking opera techniques opened on June $5,1964$.

On that day, the festival, the first such large-scale theatrical performance in China, opened in Peking's Great Hall of the People. It lasted for a month during which 37 plays were presented by 28 opera companies from 19 provinces, cities and autonomous regions. Of the 37 plays, 23 dealt with "China's present revolution and construction and the rest reflect past revolutionary struggles." 42

Many party bigwigs attended the festival. Lu Tind-yi, Director of the Department of Propaganda of the Central Committee of the Chinese Communist Party, delivered the main speech. There was nothing new in his speech. Like chou Yang in 1958, Lu also made some ritualistic remarks about traditional Chinese opera such as "we advocate that 42. SCMP, No. 3235, p. 18. 
historical operas which have educational sianificance should be refurbished from the viewpoint of historial materialism" or "we have never been opposed to the performance of some of the better traditional operas。" He went on to say that "Opera must produce fresh revolutionary flowers, portraying revolutionary events... and portraying the class strugale and productive construction since liberation。"43 Mao Tse-tung, Liu Shao-chi, Chou En-lai and other leaders all went to see the performances at one time or another during the festival。

In the meantime, the Communist press reported wide popularity of the modern opera. For example, one report said that tickets for each of the six rounds of performances were sold out in a couple of hours and regular programs of these operas were arranged by Peking's radio and television stations ${ }^{4} 4$ Another said: ${ }^{45}$

The Central People ${ }^{0} \mathrm{~s}$ Broadcasting Station has received letters from many people in all walks of life in 21 provinces, cities and autonomous regions. Some letters came from as far away as Yunnan in the Southwest, Sinkiang in the Northwest, lleilunkiang in the Northeast and Kwangtung in the South. They asked the station to relay more Peking operas with contemporary themes. They also told the station that they hoped the theatrical companies would give performances of the operas in different parts of the country and that some of the outstanding operas would be filmed。

However, there were other reactions too. One was that many regarded this third wave of drama reform temporary just as the previous two were. Early in 1964, a newspaper in Canton reported that "a common saying among some members of the Cantonese opera asserts that the 43. Jen-Min Jih-Pao (People's Daily), June 6, 1964。 44. SCMP, NO。 3268, pa 20 。 45。 Ibid $_{0}$, No。3272, p。12。 
staging of modern plays is only 'the current fashion' and 'a gust of wind." A playwright was reported sayina to the newspaper reporter: "At present, the leadership is tiahtening its arip and we should put on more modern plays for a period of time. But drama is, after all, drama. The modern plays are scanty in content. If we continue to put on modern plays, it is difficult for us to keep on." A worker of a drama troupe told the newspaper: "The staging of modern plays is just like a gust of wind that blows for a while and then passes away." 46

In the festival of June-July, Peng Chen, mayor of Pekina, revealed that this attitude toward the third wave of drama reform also existed among dramatists ir. Peking. He warned: 47

Some people in peking circles said that the staging of contemporary revolutionary plays is just a passing breeze. We must tell them that this breeze is mighty strong and that it won't stop blowing. This breeze would stop blowina only if capitalism were restored and modern revisionists aot into power in China....

Durina the festival, Peking's chief ideological journal, Hungchi (Red Flag), editorialized: 48

China's socialist revolution and socialist construction now have a history of 15 years; the working people in our country have created historic miracles on all fronts. Some literary and art workers, however, do not see this at all and have no enthusiasm for it; they are either simply unwilling to praise and depict that strugqle or have not cone it well. on the contrary they are absorbed in canitalist and feudal culture, they still hide themselves in an "ivory tower," they stubbornly refuse to go among the masses of

46. Nan Fand Jih Pao (Southern Daily), February 9, 1964. 47. Deking Review, No。 27, July 3, 1964, pp. 6-7. 48. Ibid. No. 32, August 7, 1964, p. 8. 
workers, peasants and soldiers, and into the heat of the struggle. Their innermost soul is still a domain of the bourqeoisie; they ceaselessly and stubbornly try to express themselves in an attempt to remould the world according to their own world outlook. Among them a handful have begun to stand on the side of the exploiting classes from the very outset. Such a state of affairs cannot be tolerated and must be chanced.

Apparently, the Chinese Communist Party is determined to carry out its policy of reform. The real fate of this third wave of drama reform is too early to tell. Obviously, the main determinant is the quality of the new plays that use old styles of performance. This will not be known until the party feels it necessary to initiate yet another campaign of reform.

\section{Old Operas Promoting New Values: Some Illustrations}

Among the old Chinese plays, the Communists banned some of them and then released a number of them after revising their themes. Both the method of suppression and of revision serve the purpose of prescribing a new morality for the Chinese people. In the following illustrations both methods are included.

First, the Communists banned the opera "Yang Sze-long" to indicate the Party's disapproval of the traditional concept of "loyalty and filial piety。"

In the past, Chinese writers frequently wrote about the conflict between "filial piety" and loyalty to the state. Most of them were ambivalent on this. The communists would not permit this ambivalence.

Yang Sze-long was a general in the Sung Dynasty (960-1277 A。D。)。 In a battle with a northern tribe, the sund army lost the fight and 
General Yang was captured. But the princess of the enemy tribe fell in love with Yang and they got married. One day ceneral Yana learned that his mother was with the second expedition sent by the emperor to reconquer the tribe. That night, with the help of his wife, Yang secretly went to the border and met his mother. But he returned to his wife after the visit.

The Communists banned this opera because "it projects a concept of personal virtue that is quite compatible with attachment to alien rulers aqainst one's own people," and that "this is a harmful distortion of the proper relation between public duty and personal sentiment..." 49

Second, many traditional Chinese plays dealt with the evils of such unjust social customs as arranged marriages through which the parents sought to aain socially or politically. The Communists promoted the showing of this type of play to contrast the evil past with the new "liberation" under the Communist Party. Such is the play "Liang Shan-po and Chu Ying-tai."

The opera "Liand Shan-po and Chu Yinq-tai" was first recorded in the Tana Dynasty (618-907 A.D.). Liang and Chu were two schoolmates. But chu was actually a cirl dressed as a man so she could go to school. Chu fell in love with Liand who was not aware of Chu's being a girl. The tragedy came when Chu's parents arranged to marry her to an official's son.

\footnotetext{
49. Mei Lan-fang, "Old Art with a New Future," China Reconstructs, No. 5, 1952, p. 22 .
} 
Through an intermediary Liang was told about the whole thing。 He rushed to $\mathrm{Chu}^{\circ} \mathrm{s}$ family and proposed to marry Chu but it was too late. Liang died of grief. And as the legend went, one day when Chu was on her way to the official's family, she passed Liang's tomb and she called Liang"s name. "A sudden storm arises, the tomb bursts open and swallows her up. Then all becomes quiet, Nothing can be seen except a pair of silken-winged butterflies, bobbing up and down against the sky。o" 50

During the development of this opera before 1949, a sub-plot was added in, attributing the death of the two to a kind of "original sin。" This sub-plot was deleted by the Communist drama reformers。 The following commentary appears with the publication of the new edition:

Today, feudalism and imperialism have been uprooted from China. The happiness and equality which our forefathers could picture only as dreams have been won in real life. Seeing "Liang Shan-po and Chu Ying-tai" we feel deep relief that the centurieslond niaht of oppression has passed, never to return.51

Third, because of Buddhist influence, many traditional Chinese operas had superstitious sub-plots. Deliverance of the protadonist from misfortune would come from a supernatural power. The Communists, being atheists, are determined to wipe out this kind of solution to human conflicts。 Such is the case of the famous Kiangsu opera "Fifteen Strinas of Cash。" 52

50. Chen Lin-Jui, op. cit., p.25. 51. Loc. cit.

52. "Strinas" was an old unit for countina money in China. 
"Fifteen strinas of Cash" is a murder story. A butcher named Yu came home one day drunk. He told his only dauahter, Su, that he had just sold her for 15 strings of cash. Actually, yu was merely teasina $\mathrm{Su}$ because he borrowed the money from a relative to start a new business. But su was terrified. Not wanting to be sold as a slave, su fled home.

After Su was cone, Yu fell into deep sleep. A aambler, A.h Tsu, sneaked into the house. When Ah Tsu was taking the 15 strings of cash from under Yu's pillow, Yu woke up. They fought and Yu was killed.

In the meantime, su got lost on her way. She asked directions from a merchait, Tao, who happened to have with him 15 strinas of cash. Yu's neiqhbors, after discoverino the murcer, caught up with rao and su as they were talkina. Ihey dracdec the two to the local court.

The local jucige, without investigatina, sentenced $S u$ and Tao to the quillotine. The alleged evidence was that Tao had 15 strinas of cash and the two must have murdered $Y u$ so that $t . y$ could elope together.

It was an old Chinese custom that when a criminal was sentenced to death, a superior judge was sent by a higher court to witness the execution. This time Judde Kuana was assianed to see the execution of Tao and su. The couple appealed to him. Kuang started an investication and the two were proved innocent. The real murderer, Ah Tsu, was arrested and executed. 
Before presenting this play, the Communist reformers made several changes. In the old version, Judge Kuana started his reinvestigation only after he had a dream in a Buddhist temple which told him that the two were innocent. This scene was deleted in the new edition which emphasized Kuand's scientific way of investigating the murder case. The scene on investigation reads like a modern detective story: $:^{53}$

Kuang: (in Yu's house) Where did Yu die? Policeman: (pointing to the around) He died there. Kuang: Where was the murder tool found? Policeman: (pointina) It was found here. Kuang: When was the body examined and buried? Policeman: Three days after the murder. Kuang: Where was that murder tool?

Policeman: It was taken to the magistrate's office to be filed.

According to the Communist reformers, the moral goal of this opera is "through artistic ways to help people overcome the evil habits of the old times, to get people to be more considerate to others' lives and to cope with objective events in a scientific way." 54

We can see that the best that the Communists could do with these old plays was to revise them marginally and to promote such diffuse values as patriotism, public spirit, scientific reasonina, etc. But what the Chinese Communists really wanted was to use drama to promote its ideology and policy of nation building explicitly and positively. The old plays were not designed for that. Neither would

53. Chu su-chen Toriqinal writer) and Chen shih, et al. (participants in reforming the drama), Kung Chu Shih Wu Kuan (Kiangsu Opera "Fiften Strinas of Cash"), Hona Kong, 1956, San Lien Book Store, p. 43 .

54. Yi Pien, "The New Face of 'Fifteen Strings of Cash," Wen-Yi Pao (Iiterary Gazette), No. 9, 1956, p. i2. 
marginal revisions serve the purpose. It was no wonder that drama reform had such a tortuous path from 1949 to 1964.

Thus the only way left to the Communists was to produce modern plays that contain nothing but Communist exhortation to hard work and firm faith in its doctrine. But in order to make these plays acceptable and attractive to the common people, the Communists had to use traditional techniques. Let us study some examoles of such plays shown in rural areas and see how the Chinese peasants reacted to them。

\section{Drama Troupes in the Villages}

The rural drama troupes today are characterized by the followina:

First, they are mostly formed by the peasants themselves. They are amateur troupes.

Second, these amateur drama troupes are under the supervision of local party secretaries who decide the propaganda line.

Third, in each county there is at least one professional troupe that is mobile. Being professional, this county troupe presents better quality performances. In its propaqanda policy the county troupe deals with larcer problems while the local amateur troupes deal with small local problems.

Whether professional or amateur, these troupes are modernizers in rural China. Their main task is to promote production. A good example is the following report about "Friendship Opera Troupe" at Wuchiang county in Kiangsu province: ${ }^{55}$

55. Li Hsia-yang, "Brinaing Opera to the Village," China Reconstructs, No. 2,1961, D. 18 . 
Ever since the liberation the troupe had included in its repertoire some dramas on contemporary themes such as "Do New Things the New Way," produced in 1952 to publicize the Marriage Law, about a peasant boy and girl who, freed from feudal marriage customs, decided for themselves the kind of weddina they wanted. Now the troupe makes ever areater efforts to find plays that reflect reality and are closely tied to the central tasks of the day. During the movement for forming agricultural producers" cooperative in 1954, they presented "Get Organized for Large-Scale production and Taking the New Road" sketches which the players wrote themselves to publicize the benefits of mutual aid and cooperation. Durina a health campaign, they gave "Filling up the Pond" to educate the people about sanitation.

Shortly after the great leap forward began in 1958, the members of the company composed more than ten operas on events they were witnessing right in Wuchiang county. Among them were "For Whom Are We Leaping Forward?" which reminded rural administrators not to rest satisfied with achievements, but to keep moving ahead; "Flower of steel," about a village girl who by dint of hard work mastered the technique of making steel; and "The People's Commune is Good."

Since 1962 the urban professional troupes have increased their mobility between cities and villages. They have been marching along the same path that their former colleagues did in old times. Today they are modernizers, as described in this news story: 56

This swind of China's theater to the countryside, involving thousands of specially formed theatrical groups, is one of the ways in which socialist culture is brought to the people.

From the earliest days after liberation, theater troupes have included the rural areas in their tours. The practice has now become more widespread than ever as all Chinese people are eager these days to aid agriculture and the peasants in every way.

56. $\frac{\text { Survey of China Mainland Press }}{\text { po. } 18-19 .}$ (SCM) , No. 3052, 1963, 
In the first seven months of the year theatrical companies in Shanchai gave 5,000 performances of about a dozen plays to $1,300,000$ peasants near the cityo*

On the Inner Monaolian grasslands sinders brina ballads to the herdsmen in their yurts. Fishermen in llupeh province, Central China, saw from their fishing boats operas performed on an islet in a lake. Members of an ensemble in Ninghsia in Northrest China performed for peasants and herdsmen on the loess plateau in the midst of a storm. Lumbermen in the forests of the Lesser Kingan Mountains in Northeast China have seen first-class songs and dances.

Theatrical troupes have broucht traditional and modern operas, plays, sonas, dances, ballads and acrobatics to the doorsteps of the peasants. Not restricting themselves to townships, rural communes and production teams, they have also traversed hills and gorges to perform for small, scattered settlements. In the villages the actors live in the homes of the peasants to aain an understandina of their ideas and feelinos.

For the convenience of the peasant audience performances are aiven on the modest stades of people's communes, on ancient platform stages in village squares or on makeshift staqes on threshing arounds or by the meadow side, in market places, and tea houses. Carryina light stace props and sometimes movable stades on their tours, the troupes make areat efforts to provide good decor and lightina.

Operas and plays reflecting a revolutionary spirit and the class strugale are very popular in t. c countryside.

Stories on urban troupes' going to villages have been profuse since 1960. For example, the Wu-Sung Drama Troupe of Kirin province traveled 11,600 miles from 1953 to 1960 aivina 1,238 performances for mine workers. 57 An I zner. Mongolia troupe traveled 27,000 miles aiving 2,094 performances from 1958 to $19600^{58}$

57. IIsi Chu Pao (Drama Gazette), No. 22,1960, p. 24. 58. Ibid., No. 13, 1960, 5.5.

* This means that the attendance per play was 260 peasants. 
The number of times that a Chinese village is reached by these urban companies every year is difficult to ascertain. It depends on a variety of factors including transportation facilities and the size of the village. But a peasant can always view the performances by local amateur troupes. The average frequency of viewing such performances is perhaps not less than once a week.

Audience Reaction to Modern Plays

Now let us turn to the crucial problem of the "popularity" of these modern plays using old techniques. As we noted before, the Communist press in 1964 reported immense popularity of modern peking opera. However, Communist reports on the state of modern plays up to 1964 do not agree with the 1964 reports.

The Chinese peasants prefer traditional plays and especially those that involve relationships between male and female. A 1949 survey of rural audiences reported a slogan amona the peasants: "Will not see bad plays; will not go to expensive shows; will not see plays that are not 'sour." The report then explained that by "sour" was meant "sensation and obscenity." 59

In a 1952 survey, peasants were quoted as saying that they liked traditional operas better because the old plays "have a dramatic beginning and a dramatic end, and have songs and actions."60 A 1956 survey reported the same response and cited the following events: 61

59. Wen-Yi Pao (IIterary Gazette), Vol. 1, No. 5, 1949, p. 13. 60. Hsin Yuan, "Some Problems on Rural Dramatic Troupes," ibid., No. $2,1952, \mathrm{p}, 23$.

61. Yang Kuang, "The Difficulties in Rural Theatrical Troupes," ibid., No. 24, 1956, p. 3l。 
In some localities, the local aovernment did not permit the showing of traditional operas. Then the drama trape rave these old operas secretly. The troune would dispatch a auard outside of the theater. When a cadre was seen approaching, the quard would quickly inform the persons insice the theater and the olav could be quickly chanced into a modern one. When the cadre was gone, the sroupe shifted back to the oriainal old opera.

Furthermore, the scarcity and low quality of the new plays aqaravate the peasants' disqust with the modern plays. In the same 1952 survey cited above, a peasant said: "These new plays; they are all the same. Nothing but propadanda. Once we see the beainnind, we know what the end will be like." The 1956 survey cited above commented on the quality of some mocern drama put before the peasants:
Many of our cadres overlook the laws of art. They mix art with meetinas and discussions. They try to solve some problems in our neasants' thinking by presentina them some plays. In order to accom- plish this, many amateur troupes put propacanda with political instructions and production plans on the stage. On the surface it looks like a play but actually the actors are merely making politi- cal speeches.

Third, the rural theatrical troupes have too many supervisors and controls, as described in the same report: 62
Who guides the rural amateur aroups? The propa- ganda Department of the County Communist Party, the County Cultural Section, District and Town- ship Government, Agricultural Departmer.t and primary schools, and County Cultural Halls...

The results were inevitably red tape and inefficiency. A new script often took two or three months to be approved. Thus by

62. LOC. CIE. 
the time it was returned to the troupe for showing to the public, it had lost its timeliness。

The peasants obviously did not share the Chinese Communist Party's view of using the plays for political indoctrination. They went to see a play for entertainment, not for political lectureso To close this divergence of orientations between the Party and the people, either one or both had to move closer to the other. But it is unusual for the Chinese Communist Party to move toward the direction of public opinion for the Party is supposed to transform the Chinese people characterologically so they would move voluntarily toward the direction of the Party。 Drama is also designed to share this task of transforming the Chinese people. Yet it seemed that before 1964, the modern plays were effectively rejected by the people. Then, if the Communist reports about modern plays' popularity among the people in 1964 were correct, this would mean that the people and the party now see eye to eye. Along with the 1964 reports about the "popularity" of modern plays, there were condemnations and warnings to "some comrades" and "some people" who thought that this third wave of promoting modern plays was just another "gust of wind。" The question of whether the people will come to share the Party's view on drama will be moot for some time to come.

Growth of Theatrical Groups

In contrast to the qualitative stalemate, the quantitative growth of drama troupes on the Chinese mainland was impressive. In a typical Communist pattern of development, the hollow organizational 
structure was expanded rapidly before a substantive basis was built. This gave a deceptive appearance of genuine development. As Table I shows, the most rapid growth of drama troupes occurred between 1949 and 1950。 This may be due to the nationalization of private drama groups. Then from 1952 to 1955 growth in the drama slowed down. This was the period of stagnation mentioned previously. After 1957 the upward trend revived, perhaps because of the formation of so many modern troupes during the "Great Leap Forward."

\section{Table I}

Numbers of Dramatic Groups and Theaters in Communist China

Year

1949

1950

1952

1953

1954

1955

1957

1958

1959
Dramatic Groups

1,000

1,676

1,083

2,017

1,562

2,267

1,927

2,424

2,120

2,414

2,188

2,808

2,358

3,162

2,620

3,513

2,800

These figures do not include amateur groups. The figures from 1949 to 1959 are a composite of:

Hsi Chu Pao (Drama Gazette), No。14-15, 1960, p. 34; Shih Chia Che Shih (World knowledge), Peking, 1957, p. 36 ; Ten Great Years, Peking, Foreign Language Press, 1960, p. 207. 
The growth of professional dramatic troupes is not as rapid as that of amateur ones as Table II indicates. The amateur troupes were expanded at such great speed as part of the regime's mobilization of the population. Members of these amateur troupes are participating in yet another communist mass movement. Take, for example, the increase of professional and amateur drama troupes and workers in one province, Heilunkiang. In 1949, it had 16 professional troupes with 1,000 workers, including actors, actresses, technicians and managerial personnel. In 1959, the number of professional troupes was increased to 140 and their personnel to $10,000$. In 1949, Heilunkiang had 650 amateur troupes with 13,000 members; in 1959, the number of troupes had increased to 14,000 and their members

\section{Table II}

Number of Amateur Drama Troupes in Communist China

\begin{tabular}{lr}
\hline Year & Number of Troupes \\
\hline 1951 & from 1,000 to 5,000 \\
1954 & 100,000 (rural) \\
& 10,000 (workers) \\
1955 & 11,300 (workers) \\
1959 & 240,000 (rural) \\
& 40,000 (workers)
\end{tabular}

Sources: The figures from 1951 to 1954 are from Houn, op. cit.. p. 182; the figure of 1955 is from Fei-Chin Tsan-Kou Tze-Liao (Reference on the Communists), Taipei, Central Publishing Company, 1956, p. 28; the figures of 1959 are from Hsi Chu Pao (Drama Gazette), No. 16, 1960, p. 30 . 
to $400,000.63$ The increase in amateur drama was much bigger than in professional drama troupes and personnel. Formation of amateur troupes required less investment than did professional troupes。 But the real purpose behind this rapid development seems to be to involve as many people as possible in the political mass movements through which the regime expected to change the people's character. The population of Heilunkiang is about $11,897,308$ and if $70 \%$ of them are adults,* then, with 400,000 people participating in amateur drama activities, it means one out of 20 adults in that province was involved in this type of activity. In the nation as a whole, Table II shows that in 1959 there were 240,000 rural amateur troupes. China has about 1,000,000 villages. This means that there was about one amateur troupe in every four villages. Hence, the regime's political penetration to the population through drama is both extensive and intensive. But as we mentioned previously whether such a rapid physical development has a substantial base is a moot question. Mere expansion in apparatus is meaningless unless it is matched with effectiveness. In drama in China, that means the creation of a new Communist personality.

63. Hsi Chu Pao (Drama Gazette), No. 13, 1960, p. 5.

* People over 15 years of age comprise $70 \%$ of the total Chinese population.' 
Story-Telling in China

\section{From the Past}

Story-telling (Shou Su) has a long history in China. Like Chinese drama, story-telling in the olden times served as a medium for transmitting cultural values and also, to a lesser degree, current events.

Kate Buss calls the Chinese story-tellers solitary players and itinerant actors. She writes: 64

There is a great army of solitary players-the speaking Books--these men appear in tea houses and restaurants; their accomplishments are singing and story telling.

The itinerant actor group includes the frequently met master of a trick monkey; the strolling musicians with a drum gong to sound and a few stories to relate; and the men who are heard upon bridges and street corners chanting historical fact and adventure.

The earliest reference to story reciting goes back to the chou Dynasty (1050-256 B.C.) when a bioaraphy described a wealthy family that invited a blind man to recite poems and tell virtues to the ladies in the house. 65

Direct and documentary reference to story-telling begins in the Tang Dynasty (618-906 A.D.). At that time story-telling was 64. Kate Buss, op. cit., pp. 57-58.

65. Chen Erh-hun, Shou Su Shih Hua (History of Story-Telling), Peking, Writer's Publishing Company, 1958, p. 7. 
headquartered at Buddhist temples in the capital of Tand, Chanq-an, now called Sian in Shensi province。 66

Story-telling in the Tang Dynasty began when some monks tried to disseminate Buddhist scriptures to the lay public。 In Chang-an there were at least seven temples which were places of worship and recreation. Often monks would come out and sit in the temple yard. They would recite Buddhist teachings in vernacular language。 Crowds would gather around the monk and listen. This practice soon became popular. The Emperor of Tang endorsed this practics and issued decrees assiqning certain scriptures to be recited at certain hours on certain days。

To attract the crowds, these scripture-tellind monks began their recitals each time with an anecdote, not always relevant to the scripture. Gradually the anecdote part developed into an independent form。 Professional story-telling of non-scribture material grew from this.

Story-telling was fully develoned by the time of the sung Dynasty (960-1260 $\left.A_{\circ} D_{\bullet}\right)$. The coming of the sung ended 50 years of chaos and bloodshed that followed the collanse of the Tang. Once aqain prosperity reigned. Tea houses and wine shops flourished in biq and small towns.

Story-telling then took place in tea houses。A story-teller would sit on a platform in the tea house. Before him was a table 66. Except otherwise indicated, the history of story-tellind in China in this report is based solely on two books by Chen Erhhun. The first one is shou Su Shih Hua, op。 cit。, while the second book bears the name of Shou Su Shaw Shih (A Concise History of Story-Telling), Shanghai, Chund Hua Book store 1936. 
on which was a cup of tea. It was important that everybody could see him. Nobody would want to sit behind the story-teller, for his facial expression was often as crucial as the story. Some storytellers also accompanied their recitals with singina to simple string instruments.

The tea houses varied in size. Some were said to accommonte a thousand customers at a time.

Story-telling in the Sung Dynasty developed into a semi-formal institution. Some literate persons formed book societies ("Su Hwei") to write up material for the use of story-tellers. At the end of the Sung Dynasty, story-telling had reached its maturity in terms of scope of subjects. They could be classified as follows:

1. Popular novels about men and women, ohosts and books on morality and virtue;

2. Adventure and hero stories, includina tales about bandits or hichwaymen, etc.;

3. Dynastic history;

4. Buddhist scripture.

The style of telling the story was also more or less fixed in the Suna Dynasty. There were three main styles:

1. Narration without sinaind--mostly about historical events;

2. Narration with sinaind--novels;

3. Singing without narration--ballads, folk sonas. After the Sung came the Yuan Dynasty (1260-1386 A.D.) when the Mongols ruled China. Because story-tellers agitated for nationalism and opposed foreign rule, they were suppressed. Story-tellina then 


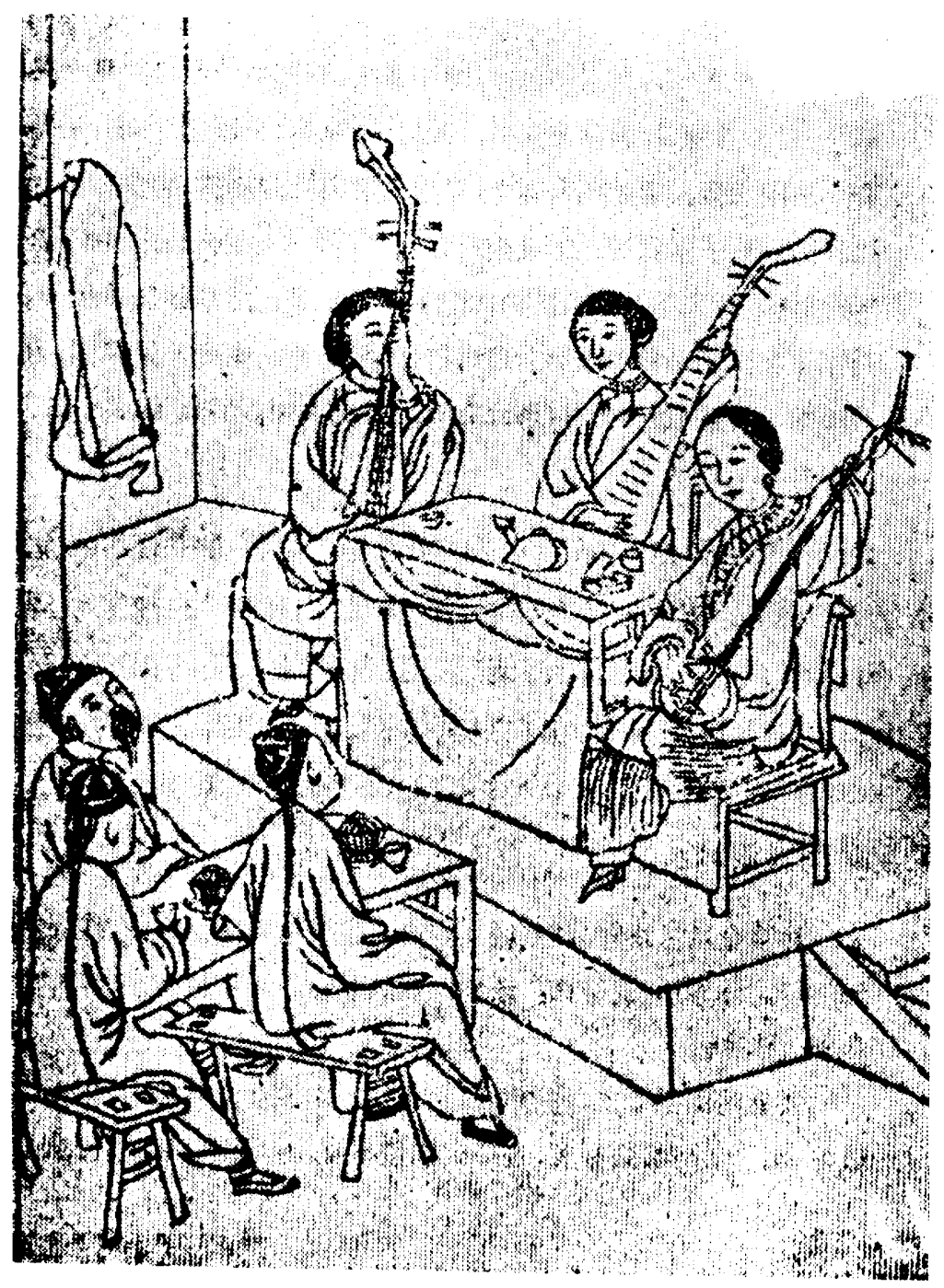

Women story-tellers in the Ching Dynasty (from Chen Erh-hun, Shou Su Shih Hua, 1958, p. 178). 
took place only at private gatherings and became associated with the secret societies. These secret societies were the centers for preserving Chinese nationalism under foreign rulers such as the Mongols (Yuan Dynasty) and Manchus (Ching Dynasty).

After the Yuan came the Ming Dynasty and then the Ching。 During the Ming Dynasty, story-tellers adopted a new technique to reinforce their narration. They began to use a fan or a piece of thin wood to pound the table in order to give emphasis to the recital. At the end of the Ching, women story-tellers appeared in tea houses, usually in groups.

After China was forced to open her sea ports to Western colonial powers at the turn of this century, story-telling flourished in big port cities which prospered on foreign investment. Shanghai became a major center for tea houses and story-telling. There, special story-telling houses were opened whose proarams included both male and female story-tellers, singing and narration. Women story-tellers became sex symbols in newspaper advertising, much in the Hollywood style.

The Traditional Social Function of Story-Tellers

Throughout Chinese history, story-tellers were of low social status and were treated as such. Many of them were blind and could not find a better way to survive. In sociological jargon, the storytellers of traditional China were the social marainals. Take, for example, the most famous story-teller, Liu Chin-tina. 
Liu was born around 1587 A.D. in a small fishing village in Kiangsu. At 15, he violated a law for which he could have been condemned to death. Liu fled. He met an old man who taught him the skill of story-tellina. Liu mastered this art at 18 and for the rest of his Iife wandered around the towns of Kiangsu, Chekiang and Anhwei. The date of his death is not known. In the ancient literature his name simply disappeared after 1666 .

As to the other story-tellers, Kate Buss writes: ${ }^{67}$

These solitudinarians, who are particularly ill paid, ill treated beyond their fellows, and as despisec as human beinas may be, have not even the companionship of their own kind to mitiaate their sad existence; they earn only a sufficient number of cash each day to buy two bowls of rice which maintain their strenath to wander.

7.Ithouah impoverished and ill treated, the story-tellers of China served an important social function. Through their telling of dynastic history, popular novels and current events, the myth and reality of chinese culture were communicated to millions of illiterates who would not have gotten that knowledae otherwise. Many of the story-tellers themselves were illiterate. They learned the trade by memorizing oral teachinas of their masters.

Among the historical novels that were told, two were particularly popular and influential. These two novels have also influenced the political leaders of modern China, notably Mao Tsetung. One of the two has been called by the communists the first Communist literature in China. A brief summary of each follows.

67. Kate Buss, op. cit., pp. 57-58。 
The first one is called San kuo (Romance of the Three Kingdoms). This is a historical novel, in 120 chapters, written by Lo Kuan-chung of the Yuan Dynasty. The plot is founded on the historical events immediately succeeding the decadence of the Han Dynasty (206-220 A.D.). It is about three rebel groups who contended for power to rule China. The first group, led by Tsao Tsao, occupied northern China and seized the last emperor of the Han Dynasty. Tsao claimed that he was the legitimate ruler of China. The second group, led by Liu Pei, occupied mainly the province of Szechuan and part of Southwest China. Liu Pei was a member of the Han royal family and claimed to be the legal heir of the lost empire. The third group, led by a former Han official sun Chuan, occupied the fertile Yangtze River delta. Eventually, one of Tsao Tsao's generals led a coup within the Tsao camp, took over the Tsao regime and then gradually conquered all of China. A new dynasty, the Tsin Dynasty (281-316 A.D.), was established and China was again unified.

In the novel, Tsao Tsao was the villain, Liu Pei the hero and Sun Chuan the opportunist. The most fascinating parts of the novel are about the feats of Liu Pei and his three lieutenants, the civilian strategist Chu-ko Liang, the invincible general Kwan Yu and the quick-tempered warrier Chang Fei. As Herbert $A_{0}$. Giles describes it, the novel 68

consists mainly of stirring scenes of warfare, of cunning plans by skilful generals, and of doughty

68. Herbert A. Giles, A History of Chinese Literature, New York, D. Appleton-Century Company, 1937, p. 277. 
deeds by blood-stained warriors. Armies and fleets of countless myriads are from time to time annihilated by one side or another,--all this in an easy and fascinating style, which makes the book an endless joy to old and young alike. If a vote were taken among the people of China as to the areatest among their countless novels, the story of the Three Kingdoms would indubitably come out first.

This is how the great commander Chu-ko Liand is said to have replenished his failing stock of arrows. He sent a force of some twenty or more ships to feign an attack on the fleet of his powerful rival, Tsao Tsao. The decks of the ships were apparently covered with large numbers of fiahting men, but these were in reality nothina more than straw figures dressed up in soldiers' clothes. On each ship there were only a few sailors and some real soldiers with gongs and other noisy instruments. Reaching their destination, as had been carefully calculated beforehand, in the middle of a dense fog, the soldiers at once began to beat on their gongs as if about to go into action; whereupon Tsao Tsao, who could just make out the outlines of vessels densely packed with fighting ren bearing down upon him, gave orders to his archers to begin shooting. The latter did so, and kept on for an hour and more, until Chu-ko Liang was satisfied with what he had got, and passed the order to retreat.

C. H. Brewitt-Taylor who translated San Kuo into English comments: 69

San Kuo is widely read and very denerally known, perhaps, however, better through stage performances than by actual reading. The San kuo is distinctly eastern, a book adapted for the story-teller; one can almost hear him。

Now the question is what the Chinese Communists have seen in

this novel that they should promote the reading of it. The following Communist interpretation seems to be typical: ${ }^{70}$

69. C. H. Brewitt-Taylor, San Kuo (Romance of the Three Kingdoms), Shanghai, Kelly \& Walsh, Ltd。, I925.

70. San Kuo Yen I Yen Chiu Lun Wen Chi (Research Articles on San Kuo), Peking, Tsou Chia Chu Pan Si (Writers' Publishing House), 1957, pp.131- 32 。 
The peasants ${ }^{\circ}$ opposition to the exploitation of landlords and rulers is reflected vividly in $S$ an Kuo. It exposes and condemns the darkness of feudal society. San Kuo has accomplished this through depictions of many complicated events and the thinking of some typical persons.o

The people ${ }^{3}$ struggle and rebellion against the ruling class are not only shown through the expose of the feudal system but also by the description of the struggles of real persons. These were the struggles between the group led by Liu Pei, Kwan Yu, Chang Fei and Chu-ko Liang and the group led by Tsao Tsao. The people expressed their desire through Liu Pei and others. The people gave them strength and talent. They gave them good qualities of thought and feeling so as to contrast them to the qualities of evil, hypocrisy, cunning and fraud, We see in San Kuo many ancient heroes politicans, generals and warriors loved by the people. These characters are not products of imagination. They are a synthesis of typical persons, a synthesis done according to historical facts and class struggles。

Another Communist writer says: 71

The fact that Liu Pei, Chang Fei and Kwan Yu became people ${ }^{0} \mathrm{~s}$ beloved heroes is because they met the desires and dreams of the people。 Leaders of peasant revolutions in history always used the slogan of "The Coming of the True Emperor" also because this met the desires and dreams of the peasants. This is not difficult to understand. These desires and dreams were feelings of the peasants in a feudal society. They reflected the immaturity and weakness of the peasant $s$ class consciousness in the pre-revolutionary period. But the important thing is that these desires and dreams conceived the revolutionary spirit。oo This is of very positive significance.

The second novel adapted for the story-teller is Shui Hu Chuan (Water Margin, or All Men Are Brothers), which the Communists have called the first Communist literature in China。

71。 Kuang Ming Jih Pao (Kuang Ming Daily), February 26, 1956 。 
Pearl Buck who translated Shui Hu Chuan into English provides both the background and a summary of the novel: 72

The story of Shui Hu Chuan is set in the thirteenth century at a period in Chinese history when the Sung Dynasty was falling into decadence and disorder under the reign of the Emperor Hung Chung. The plot is of a hundred and eight men, thirty-six of whom are chief characters and seventy-two minor. These men are compelled for the various reasons of unjust officials, or an oppressive government and evil social conditions, to flee from society and to take refuge on a great mountain set in a lake and surrounded by a reedy marsh. The mountain is situated in Shantung province, a mountain so lofty as to "look into the mists," and the marsh is threaded with winding, hidden waterways, admirable for ambush and attacks. Here these fugitives gather and organize themselves into a complex group having their own rigid laws not only of warfare but of conduct and of courtesy. There is good authority for believing that the tale is based on history, and that the thirty-six chief robbers were men who lived at the very end of the north Sung Dynasty and who ravaged central China and defied the state soldiery. Their reputation was very high among common people whom they never wantonly attacked and this fame spread far and wide and was told from generation to generation.

(The book) was probably written in the early or middle part of the Mind Dynasty in the fourteenth or fifteenth century...but more than two centuries before there were already the stories of which Shui Hu Chuan was later to be made, stories not only in prose and told by the professional story tellers, but in poems and plays....

\section{Story-Telling in Communist China}

The Chinese Communists know well the influence exerted by story-tellers. Certainly Mao Tse-tung knows how, through story-

72. Pearl S. Buck, All Men Are Brothers (Shui Hu Chuan) (translation), New York, The John Day Company, 1933, pp. vi, vii. 
teliers. San Kuo and Shui Hu Chuan became familiar to people of all walks of life in China. Edgar snow writes: ${ }^{73}$

From boyhood on he (Mao) had memorized episodes from romanticized accounts of the "Warring States" and other turbulent periods, books like the San Kuo (Three Kingdoms) and Shui Hu Chuan (All Men Are Brothers). Discussing these legends with old peasants, who also deliqhted in them, Mao heard them reminisce about heroes of the Taipina Rebellion, with whom they had sympathized... It was these epics, rich in details of strategy and tactics, and the military experience summarized in the works of Sun Wu Tzu, greatest of the ancient military experts ( $f$ ifth century $B_{0} C_{0}$ ), which were to provide for Mao, in later life, basic understanding of the arts of defense and offense in the prosecution of revolutionary war.

It is rather surprising that the Chinese communists did not seriously attempt to revive story-telling in China until 1958. For they must have known how powerful word-of-mouth communication via story-tellers could be.

Early efforts to use story-telling for political propaganda were sporadic and local. The Party branch in Tsintao, Shantung, organized a training class for story-tellers in 1950。 In that city alone 40 story-tellers underwent political indoctrination. They were instructed not to tell old stories any more, and the new scripts they used were like "Pioneer Sister and Brother" or "The Story of the Red Army"s Lona March。"74

At that period little effort was made to orqanize story-tellers into a separate profession except that some story-tellers were in73. Edaar Snow, op. cit. pp. 129-130。

74. Wen-Yi Pao (Iiterary Gazette), No.9, 1950, pp。18-19. 
vited to narrate via radio broadcasts. However, this practice had existed long before the Communists ruled the mainland.

In 1956 a ballad singing and story-tellind festival was held in Peking. Some 1,400 professional and amateur story-tellers and ballad singers attended the festival. Five hundred of the 1,400 were amateur performers from amona railway, hiahway, transport, machine tool and coal mine workers. 75

It was in 1958--the great lean forward period--that the first attemot was made to institutionalize story-tellina in the country. On Auqust 1, 1958, a nationwide conference on ballad singers and story-tellers was convened in Peking. Some 300 professionals attended the conference. Amona them was a man called rana Chao-tuna, who was reportedly the fourth generation of story-tellers in a family famous in North Kianosu province for that art. "He can narrate episodes from the classic Water Marain (Shui Hu Chuan) every night for a solid year before he completes the tale." 76

The conference formally named this art Chuyi (tuneful art). In 1958 there were 50,000 professional Chuyi artists in Communist China. If combined with amateurs, the number reached about 10 million. 77

On August 16 of the same year the Chinese Chuyi Artists' Association was set up. Its function is "to rally the country's Chuyi artists and encourage them, under the leadership of the chinese Communist party, to create and perform new works, try to recover 75. SCMP, NO. 1264, 1956, D. 22 。 76. Ib1. . No. 1835,1958, po 28. 77. Ibia., No. 1835, 1958, p. 29. 
Chuyi works from obscurity and improve the art, resolutely carry out the Communist Party's line in literature and the arts in the service of the general line for buildina socialism."78

Chou Yang, deputy directory of the Propaganda Department of the Central Committee of the Chinese Communist Party, delivered the first policy speech on the modern task of Chuyi: ${ }^{79}$

Chuyi, an art much to the taste of the mass of the people, is capable of reflecting at short notice the new things in social life and is most suited for the carrying out of mass propaganda because of its concise form. To develop this art, works that reflect the new life must be produced in the greatest number. The subject matter of the new works should be broad in scope and varied in form. While new people and new things should be described, revolutionary stories in history could also be included. Chuyi might be used to praise the new as well as to satirize what is backward and conservative.

After 1962 story-telling suddenly became one of the most prominent of the propaqanda media on the Chinese mainland. Communist press reports on story-telling were profuse. For example, in Soochow Special District, there was an average of one tea house featuring story-telling every three or five miles in 1963.80 In Chengchow County, Kiangsu, 813 story-tellers were trained from 1962 to 1963. The same county was reported to have 60 to 70 story-telling houses. There was at least one story-telling tea house in every commune and some communes had three or four such houses. It was reported that in Chengchow, an average story-telling which lasted roughly one and a half hours had an audience of about 300.81 If the population of 78. SCMP, No. 1838, 1958, p. 30 . 79. LoC. cit.

80. Jen-Min Jih-Pao (People's Daily), December 28, 1963 . 81. Kuang Ming Jih Pao (Kuang Ming Daily), February 5, 1964. 
Chengchow County was close to the average population of a Chinese county, which was 300,000 , then with 813 story-tellers, one storyteller would serve 368 persons. In Huchia County, Szechuan, four tea houses featuring story-telling served its population of 2,000. Presumably, there were at least four story-tellers and each would then serve 500 persons。 ${ }^{82}$

Another report in 1964 stated that ${ }^{83}$

Over 4,000 spare-time story-tellers are at present active in counties and towns on the outskirts of Shanghai... with at least one or two story-tellers assigned to every production brigade of the communes in these places. A number of communes have even provided every production team with a storytelleroo. In Sungchian County alone, nearly half a million people attended story-telling meetings last year.

Telling Political Stories

Currently Communist stories are steeped with political propaganda. The following Chinese report illustrates this: 84

The stories popular among the masses include famous ancient literary works as well as worthless dregs. The contents of the old works are mostly about the "merits and great achievements" of emperors, kings, generals and ministers.... With regard to ideology and sentiments, these stories are remote from the laboring people who are now engaged in socialist revolution and construction, and therefore they do not meet the needs of the masses. Some other stories which contain feudal superstitions and bourgeois poison should not be allowed to continue poisoning people. Therefore, when we promote story-telling, we must promote the telling of new and revolutionary stories. In

82. Fan Sui,"In a Szechuan Teahouse," China Reconstructs, Peking, No。 4,1964, p。12。

83. Chunq-Kuo Chinq-Nien Pao (China Youth Daily), March 19, 1964. 84. Kung Jen Jih Pao (Workers' Daily), March 24, 1964 . 
praisina merits and achievements, we should select the merits and achievements of the workers and peasants in the momentous revolution; in telling tragedies, we should denict those of the laboring people caused by two entirely different destinies in the new and old societies; in describing dangerous and eventful adventures, we should tell those of the revolutionary heroes who defeated the enemy and won victories with ingenuity and courage. In particular, we should talk more about new men, new events, new ideas and new customs of the present time. In short, the laboring people and revolutionary heroes should be the leading characters in stories, and revolutionary strugales and construction should be the main subject matter. Through these characters and subject matter, we can attract the masses and propaqate revolutionary ideas amona them and transform them qradually. Only in this manner can the traditional form of story-telling be improved and serve socialist revolution and construction.

The contemporary story-tellers in Communist China are party propacandists. Take, for example, the case of Chinshan County on the outskirts of Shanghai: 85

Story-tellers are the back-bone elements of the Party; they are aood in ideology, labor and working style and recommended by the basic-level Party organizations. For instance, over $60 \%$ of those attending the story-tellind training class in Chinshan County are party and Leaque members. At the training class, it was emphasized that theories should quide practice in continuously conducting political and ideological education. Therefore, the story-tellers have basically become a proletarian army of spare-time literary and art propagandists.

Even the tea houses went through a Communist transformation. The following report describes the transformation of a villace tea house in suburban Shanchai $:^{86}$

85. Kuang Ming Jih pao (Kuang Ming Daily), March 18, 1964. 86. Peking Review, No. 38, September 18, 1964, D. 30。 
In shanyang town in the shanghai municipality, the main teahouse seats 200. Any noon hour finds it filled to capacity. Its physical appearance has changed from the old days--gone are the blaring music, vulqar exchandes and tobacco company "beauties" which once adorned the walls. Today it is clean, white-washed, sanitation-conscious. The pictures and posters on the walls reflect the life, tastes and campaigns of its patrons at its neat tables: sun-browned commune peasants. There is the buzz of talk, jokes and laughter between old friends and new acquaintances. In an inner room seating another hundred people, a story-teller with a hand-clapper tells a new story of how a farm brigade changed the face of their land from poor to prosperous.

As we see, the Communist story-tellers are supposed to tell modern stories about socialism, class struggle, labor, etc. But in order to retain audience interest, traditional novels like San

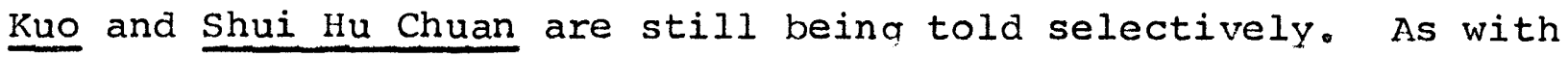
traditional opera, old stories were also revised or given new interpretations to suit the Communist cause. For example, one episode in Shui Hu Chuan told of Wu Suna, a hero, who beat a tiger to death with bare fists. The Communists have now made the tiger a symbol of "imperialism。" Wu sung became a symbol of the proletariat, or rather the Chinese proletariat, who could beat the imperialists to death even though China does not have modern weapons; bare fists are enough since "all imperialists are paper tiqers."

But as in opera reform, the unmistakable emphasis is on modern stories. In 1963, the Union of Chinese Chuyi Artists announced that 47 modern novels had been adanted by story-tellers. Among them were such Chinese Communist novels as Tracks in the Snowy Forest, about the elimination of a group of Kuomintang soldiers in Northwest China 
durina the Civil War; and Red Rock, about the "heroic struqde" of Communist prisoners in an alleged concentration camp in chunakina managed by both Americans and Kuomintang. 87

Functions of story-Telling

From the Communist reports, we can discern four complementary functions that the story-telling should serve.

First, it was desianed to boost morale amona people durina the difficult years of the regime. Thus, for example, one report about story-telling activities amona workers in shanghai says: 88

During June and July 1962, after our country had been hit by natural calamities for three consecutive years, some employees and workers showed little confidence in overcomina difficulties. The Municipal Cultural Palace therefore oraanized storytellers to ao to the factories to tell the story Red Rock vidorously to educate the workers in the spirit of our revolutionary martyrs who made sacrifices without hesitation, defied difficulties, disregarded personal gain or loss, had faith in the party and in the revolutionary cause.

Another report about a county in Honan province stated that after the county Party secretary told the story of Red Rock to the villagers, they were reported to have replied: "Compared to them (characters in the Red Rock), our difficulties today are nothind at a11." 89

Second, story-tellers were used to stamp out rumors which could produce a detrimental effect on the morale of the population, particularly in a period of crises. On July 4, 1962, Nan-Fand Jih-

87. SCMP, No. 2961, po. 13-14,

88. Kung-Jen Jih-Pao Jorkers' Daily), March 24, 1964.

89. Peking Review, No. 16, April 19, 1963, D. 25. 
Pao (Southern Daily, Canton), published two reports on the cracking of a rumor-generatinq "spy rind。" The reports said that the main duty of this spy ring was to listen to broadcasts from Taiwan and Voice of America and then spread the news in group gatherings and in tea houses: 90

Sometimes, they (the spies) purposely spoke in a
louder tone so that the nearby tea-drinkers could
hear them. They always began each rumor with "I've
heard. ". so as to emphasize their "objective" posi-
tion. If any tea drinker sitting at a neighboring
table showed some interest by joining in the conver-
sation they would treat him as a "bosom friend of
ten years" standing" and would tell him one rumor
after another. But if someone was in doubt and
queried them, they would at once change the tenor
of their conversation by replyind: "That's right.
I don't believe it either. It may not be true."

Hence, to keep the diffusion of rumors at low frequency, the Communist Chinese authorities had to control the likely places of diffusion such as the tea houses. For example, in Sunchiand County near Shanghai in 1964 there were 76 tea houses which featured storytelling. In that year 54 of them were taken over by "amateur storytellers who told stories about revolution."9l story-tellers were even dispatched to places where people usually came together in the evenings in the summer to enjoy the cool breezes.* The People's Daily commented on this: 92

But what to talk about may make a great difference.

Although in the past some people would talk about major events in the world,... many others either talked

90. Nan-Fand Jih-Pao (Southern Daily), July 4, 1962.

91. Chung-Kuo Ching-ivien Pao (China Youth Daily), March 19, 1964.

92. Jen-Min Jih-Pao (People's Daily), July 23, 1964.

* It used to be a Chinese custom for people to go outdoors on summer nights to enjoy the cool air. 
about gods and spirits or about eating and drinking.... This led the mind of people astray and turned their thought to superstition and to enjoyment of the material comforts of life.

But now the bad customs have been changed; nowadays people tell revolutionary stories and factory and family histories, or sind revolutionary sonqs and give modern plays, etc. This shows that our society has had a new outlook and that people's spiritual mien has displayed a fresh vigor day after day.

But how did this change come about? The People's Daily then reported: 93

In the past several days, many neighborhood committees and lane organizations have held storytelling sessions (in Shanqhai, 1964) in the evenings. The story-tellina group of Chapei district has sent teams of three or four narrators to seven selected spots, includind Hotien Road, Yenchiako Road, Chunghuahsin Road and Taiyangmiao Road, where many people gather to enjoy a cool evening to tell stories about the revolution every day or every other day. In addition, over 100 lane narrators in this district spread out to the sidewalks of the street, in the lanes, or on the rooftops to tell such revolutionary stories as Criminal Evidences Stained with Blood and Tears, Two Pairs of Shoes, A Chicken, The Secret of a Wall, and Capture Huang Hsiu-chang by Strategy to small groups of residents.

Hence, this so-called new "spiritual mien" of the people in Shanghai was nothing but another instance of mobilization or politicizing of the population by the Communist party.

Third, story-telling was also designed to produce immediate action consequences. For example, a story-teller in a railway workers' club told of his method of telling stories to "scattered listeners"-person-to-person agitation ${ }^{94}$

93. Jen-Min Jih-Pao (People ${ }^{\circ} \mathrm{s}$ Daily), July $23,1964$. 94. Kung-Jen Jih-Pao (Workers Daily) , March 24, 1964. 
oo when story-tellex Chang Kuo-tung of the Electric section saw the comrades in the laboratcry throw the odds and ends of electric wires into dust-bins, he told them a story about the good habit of the workers in sunchiatun in saving even a nail or a piece of wood chip for the state. Now no more odds and ends of electric wires can be found in the dustbins. Aiming at the self-complacency and lethargy of some members of the No. 3 train crew (a red banner crew), story-teller Tu Wei told them about the Sunchiatun workers' high standards and greatly educated them. After he had finished his story, crew leader $W u$ shu at once took the lead to examine himself and expressed his determination to correct his mistake。

Another story-teller writes of his experience: 95

When I heard that a certain locomotive driver was too interested in his bonus, I told him the story about the "Old 3rd Grade" of Sun-chia (section) and let him learn from them the noble quality of accepting any amount of reward. He was enlightened. When I found that a worker used an excessively lona piece of wire in making oil-wicks, I told him the story about the workers in Sun-chia in saving every inch of wire. He was areatly moved by the story and began to improve his tools... From these facts it is clear that telling revolutionary stories to the workers is also an important political work.

Fourth, story-telling was designed as a means of socialization or indoctrination of the young generation to enable them to carry on what Mao Tse-tung in Trotsky's phrase called the "permanent revolution."

Since 1962, the Peking leaders have been seriously concerned about the quality of the second qeneration. This concern was spelled out clearly in an article in the Chung-Kuo Ching-Nien Pao (China Youth Daily), the Party's leading newspaper among the youth. Using a case in Honan as an example, the article says: 96

95. Kuna-Jen Jih-Pao (Workers' Daily), March 24, 1964 。 96. Chung-Kuo Ching-Nien Pao (China Youth Daily), November 30, 1963. 
It is important to inculcate class struggle in youths and children in order that they will be able to pass on the torch of Communism. The younger generation of today have been brouaht up in the socialist society, with all the blessings of the Party and people. Not having gone through the tribulations that all working people experienced in the old society, they are naturally not as class-conscious as their elders.

Despite the fact that the past reactionary ruling class was overthrown, class strugale has not ceased. Class consciousness, in fact, has to be passed on from generation to generation...

The minds of youths and children are usually not as susceptible as adults to theoretical abstractions.... They must be assisted by the presentation of concrete facts and qraphic data. During the socialist education campaian in Honan, special emphasis was given to the re-telling of personal experiences of old workers and old poor, lower and middle peasants. The spoken words of those agdrieved under the old society was a monument of convincina truth.

Through the person-to-person approach, all questions which the youths may have could be immediately answered with illustrations from first-hand experiences. This matter-of-fact method proved to be most effective.. particularly among those youths born of families of workers and poor, middle and lower peasants. In these families the stories of those adults were poignantly convincing when retold today. No text books could substitute or even come near to them in lucidity.

Among all the youths in China, the Chinese Communist Party pays special attention to the rural ones. It is from these rural youths that the party draws its new blood. Hence, their ideological purity must be insured. The Communists have not been satisfied with the state of morale of these youths, as the following report shows: 97

Although our cultural cosition in the countryside is socialist, the influence of old culture and ideas of feudalism and capitalism is still present there. Our class enemies are still trying to use old stories

97. Chung-Kuo Ching-Nien Pao (China Youth Daily), March 19, 1964. 
about emperors and kinas, generals and ministers, talented scholars and pretty damsels, heroes and warriors, gods and spirits, witches and demons as a weapon for fiahting with us for the mind of our younger generation.o. Telling stories of the revolution is one of the most effective ways of promoting proletarian thought and destroying bourgeois thought and occupying the cultural position.

In order to make these youths class conscious, the Communists enqaged elders to tell their "bitter stories" of the past to the youngsters. In ore county in Anhwei province: 98

Poor, low and middle peasants were invited to give talks on their histories in homes, in mess halls, and by the fields; talks on village and family history were promoted. Li Yuna-chiu, a junior middle-school araduate, had always thought that his talents were not utilized and had been rather unhappy. During the early phase of the education movement he stood aside as if it had nothing to do with him. In Auqust the history of his family was told. His mother wang Su-chen, an old model worker, said at the complaint session: "My child Yund-chiu, you really don't understand things. You were born when your older brother was 16 , about the age to be drafted. I was afraid that people miaht know I had two sons and I let your hair grow long and made you look like a girl until the liberation. I was hopina that you would grow up to be a person with lofty ambitions. You must not disappoint me。" Li Yung-chiu was moved and left for the field to pull weeds even without eating his meal, and has now become an active element.

The more the older reneration talked, the greater their grief and their excitement and the longer their tales. The young people were made to feel that in the old society poor peasants were crushed under the vast mountains of feudal reactionary power. Youth Tsang Lien-san and Li Hua-nan now understand that if it weren't for the Communist Party and Chairman Mao, how coula we live today.

98. Chunq-Kuo China-Nien Pao (China Youth Daily), June 20, 1964. 
Such story-telling was also carried out in urban areas in

factories。 In Fushun Municipality, Liaoning province, old workers were organized to tell the bitterness of the past: 99

From old workers we organized story-tellers, who had been trained before, to tell stories about the new society and the old one, the past miseries and the present happiness. They not only tell such real stories as "Enmity of Three Generations" and "Three Debts of Blood," but also composed such stories as "Miners of Two Generations," "The First Half of My Life," "Hatred of the Poor People" and "The Childhood of Three Miners." These stories develop in the workers and employees a deep hatred against the old society and love of the new one. After hearing these stories, Tsui Chuan-fang, wife of a miner of Lungfeng Colliery, said: "We can never finish telling the miseries of the old society. Now, whenever I take up my bowl, I think of the Communist Party; whenever I take up my chopsticks, I think of Chairman Mao. Had it not been for the Communist Party and Chairman Mao, people like me would have been tortured to death long ago and could never have survived till today."

At universities, telling stories of such nature was carried

out in the so-called reminiscence and comparison rallies. For example, at Kiangsi University: 100

At the reminiscence and comparison rally held by the biology department, Nieh Shui-ken, a new student of the university whose immediate forebears had begaed for three generations, told the tragic story of his family. Throuah reminiscence and comparison, there has been considerable strengthening of the proletarian class consciousness among the students; they began to recoanize their purposes of study more clearly.o.

At this point one may justifiably wonder why story-telling should be sinaled out to perform these functions when any mass medium can do the same.

99. Kund-Jen Jih-Pao (Workers' Daily), May 24, 1964 。 100. Kuang Ming Jih Pao (Kuand Mind Daily), October 25, 1964 . 
Advantages of Story-Telling as a Mass Medium

The answer is partly provided by the Communists themselves: 101

Why is story-telling so popular amona the masses?

Through analysis, we can at least find the following reasons. First, it is economical. No costumes, settings, lights, scenes or musical accompaniment are needed. It is not restricted by time, location or by the number of people attending. Stories can be told at any time or place, and the technique of story-telling is comparatively easy to grasp. Everybody knows how to tell stories。 secondly, story-tellina uses common language and is easy to understand. Some people who do not have the high cultural standard required to read difficult books are able to learn the content of these books by listening to stories. Thirdly, story-telling is quick and lively. Stories can be told as soon as they are compiled.o..

Furthermore, unlike the impersonal formal media such as radio and film, story-telling is a genuine "people's art。" It is less formal than the Peking opera and belongs more to the common people than to the officials and scholars. This also made it easy for the Chinese Communist Party to renovate it without much opposition。

The high mobility of story-tellers and their personal touch enable them to cope with such unique problems as stamping out rumors . Surely no other media can be more effective in penetrating into the people than the story-tellers.

101. Kung-Jen Jih-Pao (Workers'Daily), March 24, 1954. 


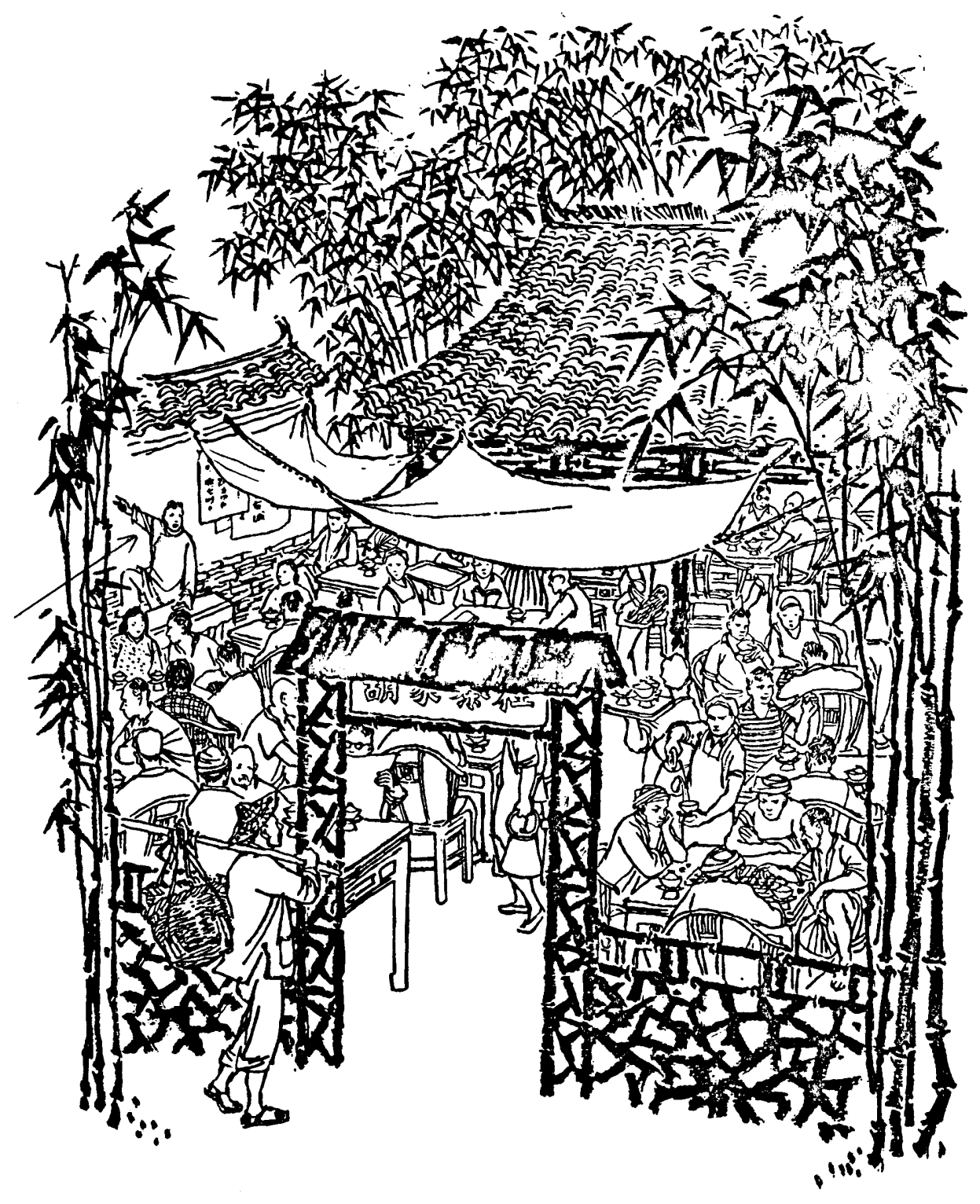

Drawing by Lin Kai

The Huchia teahouse of Szechuan province. The story-teller is at the left side of the picture (from Fan Sui, op. cit., p. 12). 


\section{$\mathrm{V}$ \\ Songs, Poems and Aaitation}

From 1949 to 1958

Like all forms of art and literature, songs and poems must also serve the Party in Communist China. For, as Chou Yang, deputy director of the Party's Department of Propadanda, says: ${ }^{102}$

They (sonas and poems) have become a mode of political aqitation in factories and farms. Weapons in the strugale to increase output, and the creation of the laboring people themselves, they are at the same time works of art the people can appreciate.

The Communists started early to turn folk sonas and poems into weapons of aditation.

In 1953, during the lunar New Year holidays (February 14 to 28), sond festivals were held in every part of China. The Ministry of Culture sent 160 composers, dancers and playwriahts to observe these local festivals and to collect data for research. 103

Subsequently on April 20 of the same year, a two-week folk music and dance festival was held in Pekind; 300 artists attended and 100 performances were given.

In 1955, the National peasant and Folk Music and Dance Contest was convened in Pekina. During the contest a special feature was the presentation of a variety of dances and sonas from china's 102. Chou Yang, "New Folk Songs Blaze a New Trail in Poetry," Chinese Literature, Peking, No. 6, 1958, p. 8. 103. SCMP, No. 507, 1953, o. 9. 
minority races. These minority races are known for their rich folk songs and ballads. 104

The next year a special ballad singers' festival was held in Peking, attended by some 1,400 professional and amateur ballad singers and story-tellers。 Songs and stories allegedly written by workers were recited. 105

These conventions and festivals served for exhibitina the results of research into Chinese folk songs and ballads. During this pre-1958 period, serious research was carried out to preserve old Chinese songs and ballads. For example, a research team was sent to Sinkiang for the sole purpose of recording folk songs from a well-known Uigur folk singer, Jantzu Tambol. This recording consisted of 167 songs which told of the history of the Uigur race, its wars and religion. 106

In nomadic Mongolia mobile cultural centers on horse cart collected folk songs, poems and stories of the Mongol people。 107

Then came 1958, the year of the great leap forward. This movement demanded from the peasants mass production of songs, poems and ballads. One forum came after another, and the line was set for creating more modern songs.

With respect to folk songs: "Instead of dealing with the suffering and sorrow of the people as the folk songs did in the old days, in the new folk songs, the working people give a timely 104. SCMP, NO.1015, 1955, p. 18 。 105。 Ibid., No。1264, 1956, p. 22。 106. Ibid., No. 663, 1953, pp. 16-17. 107. Ibid., No. $1750,1958, \mathrm{p}$ 。34。 
reflection of the country"s rapid development, their ability to do what seemed impossible and the happier life they are building。"108 The instruction is that "the poets must change their work style, strive to compose the kind of poems and songs best liked by the masses, and learn to use the simple and straightforward style and language from the folk songs and ballads."109 Jen-Min Jih-Pao, the Party" ${ }^{8}$ chief organ, openly scorned scholarly researches on folk literature: ${ }^{110}$

This is no longer a kind of research work that can be carried out by a few scholars in their libraries. It should not be left aside to be collected and edited bit by bit by a small number of expert and literary and art workers, thus having less and poorer work carried out at a slower rate and in a more expensive way. It should depend on the whole Party and all the people to achieve greater, faster, better and more economical results.

And the Communists did achieve greater, faster and more economical results. Sonas like the following one were mass produced: ${ }^{11}$

Where is the farm without song, Where is the home without poem; The more we sina, the more we produce, poems turn into rice and songs into grain.

Throughout 1958, a fantastic amount of literary creation by illiterate peasants was reported. Thus at the Nanpo Cooperative of Kulan county in Szechuan the peasants in a few months ${ }^{\circ}$ time wrote 10,000 folk songs, 60 short plays, 30 ballads and composed 10 dances. A spokesman for the Szechuan Provincial Cultural Bureau reported that the province had more than four million amateur writers in its 108. SCMP.NO 1835,1958, p。29。 109。 Ibid。 No。1773, 1958, p。16。 110. Jen-Min Jih-Pao (People's Daily), August 2, 1958 . 111. SCMP, NO 1891, 1958, Po19。 
population of 62 million and 86,700 writing groups; $78,450,000$ works, mainly folk songs, had been written and 3,700 booklets of collections of poems and ballads had been published. 112

Everywhere the peasants were turning out sonas, poems and books. The subjects were surely the Party, the central tasks and the bumper crops. Peasants were made members of literary societies. The Canton Branch of the Union of Chinese Musicians accepted 11 folk singers into its organization. 113

After the great leap forward in the economy came to a halt in early 1960, the singing movements became louder and louder.

The Socialist Singing Movement in 1963

In late 1963 the Communist government launched a "Socialist Singing Movement." The people were urged to "vigorously sina revolutionary songs" throughout the country "in order to arouse [their] enthusiasm in Socialist revolution and socialist construction。"

In addition to the songs recommended in accordance with local conditions, the nationwide Union of Chinese Musicians recommended the following songs: ${ }^{114}$

$$
\begin{aligned}
& \text { 1. "Sing a Ballad for the Party" } \\
& \text { 2. "A Broad Path Before Us" } \\
& \text { 3. "Everybody Sings of the Good 8th Company" } \\
& \text { 4. "Learn from the Good Example of Lei Feng" }
\end{aligned}
$$

II2. Loc. Cit.

113. SCMP, No. 1808,1958, D. 45.

114. "The Socialist Singing Movement," Union Research Service, Hong Kong, Vol. 33, No. 25, December 24, 1963, pp.393-394. 
5. "Obey Only the Party"

6. "Proletariats of the Whole World, Unite"

7. "The Commune Members are Sunflowers"

8. "Hold Aloft the Great Banner of Revolution"

The verses of the song, "Sing a Ballad for the Party," are:

To sing a ballad for the Party,

I compare the Party to my mother.

My mother gave me only my body,

But the Party's brilliance lights up my heart.

When the old society whipped me,

My mother could only shed tears;

But the party called me to join the revolution,

And I snatched the whip to flog the enemy。

The Kung-Jen Jih-Pao (Workers ${ }^{\circ}$ Daily) said that when groups of people, ranging from several tens to several hundreds and several thousands, sing together at ordinary times or on festive occasions such songs as "The Internationale," "The National Anthem of the People's Republic of China," "The East is Red," and "Singing the Song of the Motherland," the emotional impact is tremendous and people will be greatly stirred。115

To see the degree of penetration and mobilization of the masses by this movement, we shall describe the movement at three localities: Yangchuan, Shanghai and Canton。

In Yangchuan, the singing movement was led by the Propaganda Department of the Municipal Party Committee. Since the workers were the first group to be mobilized, the Municipal Trade Union set up organizations at all levels of its subordinate bureaus for mobilizing workers to sing. The usual method was to hold inter-factory or 115。 Kung-Jen Jih-Pao (Workers ${ }^{8}$ Daily), Auqust 8, 1963. 
inter-mine singing contests。 During the contests, the local party secretaries were often the leaders of the teams。 116

However, singing did not exist just for the contests. It was made a part of daily life. Thus "on festivals or in coordination with political movements, large-scale singing activities were launched; singing contests, sinaing soirees on special subjects, commendations and prize-giving meetings were also held。 At ordinary times, teaching of singing was done durina work breaks, before meetings, before work, before meals and in other spare time。" 117

Workers' cultural halls were utilized to train singing teachers, who then went out (to the street) to form the so-called "song-teaching stations" to mobilize the residents to sing. In Yangchuan, there were, by 1963,700 such song teachers and 300 song-teaching stations. primary school teachers were mobilized to go into residential areas to teach singing. Song teachers went to theaters and taught the audience to sing before the shows started。

As a result of this large-scale mobilization, Yangchuan had quite a record:

1. In 1961 a singing movement was promoted for the 40 th anniversary of the Communist Party. Some 80,000 people learned to sing "Obey Only the Party," "Yangchuan is a Good Place," and "Chairman Mao is Really Great"; some 65,000 people could sing

II6。 Kung-Jen Jih-Pao (Workers" Daily), Auqust 13, 1963 。 117. LOC.Cit. 
"Nanniwan,"* "All Look to the Party," and "Sing of Happiness Over All Places"; and 20 percent of the coal mine workers learned to sing "The Yangchuan Colliery is Good" and "The Mines Are Good." 2. Between May $I$ and June 10, 1963, some 80,000 to 90,000 people learned to sing "Learn from the Good Example of Lei Feng";** some 40,000 people learned to sing "The Commune Members are Sunflowers"; and more than 10,000 people learned to sing the "Internationale" and "All Love the Commune as One." In some units, 70 percent of their employees participated in singing.

In Shanghai a mass singing contest lasted for three months, from June 7 to September 7, 1963. During the contest hundreds of amateur choruses held more than 100 competitions ranging from the district and county level on up to the municipality. 118

The choruses participating in the contest were formed by all sorts of people in Shanghai: workers, students, soldiers, commune members, retired veteran workers, professors, engineers, doctors, returned overseas Chinese, covernment officials, housewives and others. The number of members in a chorus generally ranged from II8. Kuang Ming Jih Pao (Kuang Ming Daily), september 15, 1963.

* "Nanniwan" is situated southeast of Yenan; the place became famous as the Communists reclaimed the land during the Yenan period. The song "Nanniwan" is to sing the praises of the Nanniwan spirit.

* Lei Feng was supposed to be a squad leader in a transport company in the Communist army. He was killed in a car accident in 1962. He was supposed to be a model soldier and possessed all the virtues that a Communist soldier is supposed to possess, among which is reading Mao Tse-tung literature. After Lei's death, he was claimed as a hero and his loyalty to the Party was called a model for others to follow. 
100 to 500. The chorus of Shanghai steel and textile workers had some 1.200 members with a brass band of 100 players. Thirty-six professors of the Shanqhai No。 1 Medical College formed a chorus。 From the Shanghai Municipal Architectural Design Institute, 108 engineers formed a chorus。 119

Housewives were organized into choruses by streets. The North Honan Road"s "Street and Lane Committee" in Hungkou district organized 108 women who sang "East is Red" in the streetand-lane singing contest. This group of women gave over 100 performances in factories. 120

In Canton the mobilization for socialist singing was no less intense than in Shanghai. In the factories, loudspeakers were used to promote singing. In the streets, young agitators were sent to persuade housewives to participate in singing. One such story follows: 121

In this street (Tatuna street, Canton), there lives another young woman who was deeply poisoned by bourgeois thought and whose style of life and attitude towards love were improper. The youth group, aiming at her fondness for singing, quided her to give up unhealthy lyric songs and sing instead revolutionary lyric songs such as "No Tears, No Sorrows" and "Chairman Mao is Forever With Me" as a step to gradually change her thought. After a period of enlightenment in various ways, she has now made much improvement and has become an activist in youth activities in this street.

since everybody must sing, so must the children. Furthermore, children can be efficient agitators and rumor carriers. Thus it

II9. LOC CIt。

120. LOC.Cit。

121。 Nan-Fang Jih-Pao (Southern Daily), October 17, 1963。 
was found in the Central Huaihai Road Pximary School in Shanahai that "during a certain period of time, a few pupils learned some bad children's ballads from outside the school and spread them in the school. Some children failed to do their homework but learned to hum ballads with unhealthy ideological content. Aiming at this situation, the teachers of the Young Pioneers' Corps taught the children to compose and sing new and good children's ballads." 122

And what were the new children's ballads like?

First, "Praise the Communes," which reads: "Little, little birds, singing on the trees, praising the oxen and goats arowing so strong; praising the grain piled up so hiah; praising the ponds teeming with fish and shrimps; praising the communes so good." 123

Second, "Support the Young Negro Brothers," which reads: "Little white pigeon, you are really beautiful! Fly to Africa quickly, to tell the young Negro brothers that we support them forever。" 124

On March 25, 1964, the Central People's Broadcasting station (Radio Peking) and two music magazines sonsored a national poll on songs. The aim of the poll was "to encourage creative writing of Crinese music that reflects the contemporary era of socialism, and to popularize outstanding songs among the people."125

The result of the poll was published on september 4 . It was reported that 11,950 people and groups cast votes and 26 songs were selected as the most popular. These included "Proletarians of the T22. Wen Hui Pao (Wen Hui Daily), November I, 1963.

123. Ibid. October 27, 1963.

124. $\overline{\text { LOC. cit。 }}$

125. SCMP, NO. 3173, D. 11 。 
World, Unite," "Walking Along the High Road," "Hold Aloft the Banner of Revolution," "Always in the Forefront in Building Socialism," "Sing a Folk Song to the Party," and "We Are Successors to Communism." 126

Thus in story-telling and ballad singing, Peking did not meet serious obstacles in their process of reform. This was largely due to the fact that these two were genuinely people's art. They had no intimate relation with scholars as the Peking opera had. The smoothness of the process of revision, however, should not be equated with the probability of its effectiveness. People may be coerced not to sing old ballads and to participate in group singing, but whether the words of the new songs have any effect in changing their attitudes depends first and foremost on their inner convictions.

126. SCMP, No. 3295, pp. 17-18. 
Poetry Recitals

Traditional China did not have the custom of mass gatherings for poetry recitals. A poet would do to a bar or tea house with fellow poets or with his admirers. There the poet after a few drinks would compose and recite. His faithful disciples would write down the poems. Sometimes, the owner of the tea house would be delighted to post the posms on the walls to show the intellectual atmosphere of his shop。

In Communist China poetry recital or reading inevitably has become a medium for political propaganda. As a Communist writer says : 127

Since the liberation the tradition of using poetry-reading as a weapon against imperialism has been continued and broadened. Poems were a call to battle during the war adainst U.S. aggression in Korea. They have been read aloud at many demonstrations expressing solidarity with Cuba or denouncing imperialist aggression and supporting the national-democratic revolutions in Asia, Africa and Latin America.

Poetry-reading has also acted as a call to socialist construction and given expression to the people's zeal for building a new life.... Many schools, factories, army camps and qovernment offices now have amateur poetry-reading groups.

Peking, the traditional cultural center of china, is now too the center of the new revolutionary literature. Since 1958, it has 127. Yin Chih-kuang, "Poetry Heard by Millions," China Reconstructs, Peking, August, 1963, pp. 27-28。 
been the major site of mass poetry-reading。 on May 11, 1958, a poetry-reading for workers and peasants was held. It was attended by more than 1,000 people and some 20 poems were recited. A worker at the Fentai Railway station recited a poem about the young workers $^{\circ}$ determination to become mature politically and professionally and to overtake Britain in 15 years. Poems on the Ming Tomb Reservoir were recited by students who took part in its construction。 128 On september 5, 1962, a less political recital was held in Peking。 It was attended by 500 poets and poetry-lovers. Many kinds of poems were recited: ancient and contemporary, literary and political, foreign and domestic. Some 30 poems by the ancient Chinese poet $\mathrm{Tu} \mathrm{Fu}$ were read, as were the works of the Communist poet Wen Yi-tuo, Shakespeare and Mayakovsky. Two poems by Mao Tsetung were sung to ballad music in both southern and northern styles。 129

During 1962 the Central People's Broadcasting Station frequently sponsored poetry recitals and then rebroadcast them. In the station's regular broadcasting schedule, poetry recitals often assume the form of a poetry-play in which poems are both read and sung, constituting a new form of opera.

The places and forms of recitals are varied. Since 1962 , some recitals have been held in theaters, and tickets are sold. According to a Communist poet when a recital of this kind was first held in Peking, "every programme drew a great crowd outside the theater listening to the readings over a mobile public-address system." 130 128. SCMP, No。 1773,1958, p. 24 . 129. Ibid., No, 2816,1962, p. 24. 130。 Yin Chin-kuang, op. cit。, p. 28 。 
There are also mobile poetry-reading groups which, sometimes, travel with the play troupes. In 1963 a mobile poetry-reading group went to a commune near Peking and gave a recital to some $3,000 \mathrm{com}-$ mune members.

By and large the new poems recited are political poems designed for agitational purposes. A special feature is that many of these recitals have dealt with international events. An example is a poem called "Offensive Logic and Offensive Weapons," satirizing Kennedy's speech on the Cuban Crisis. The poem reads: ${ }^{131}$

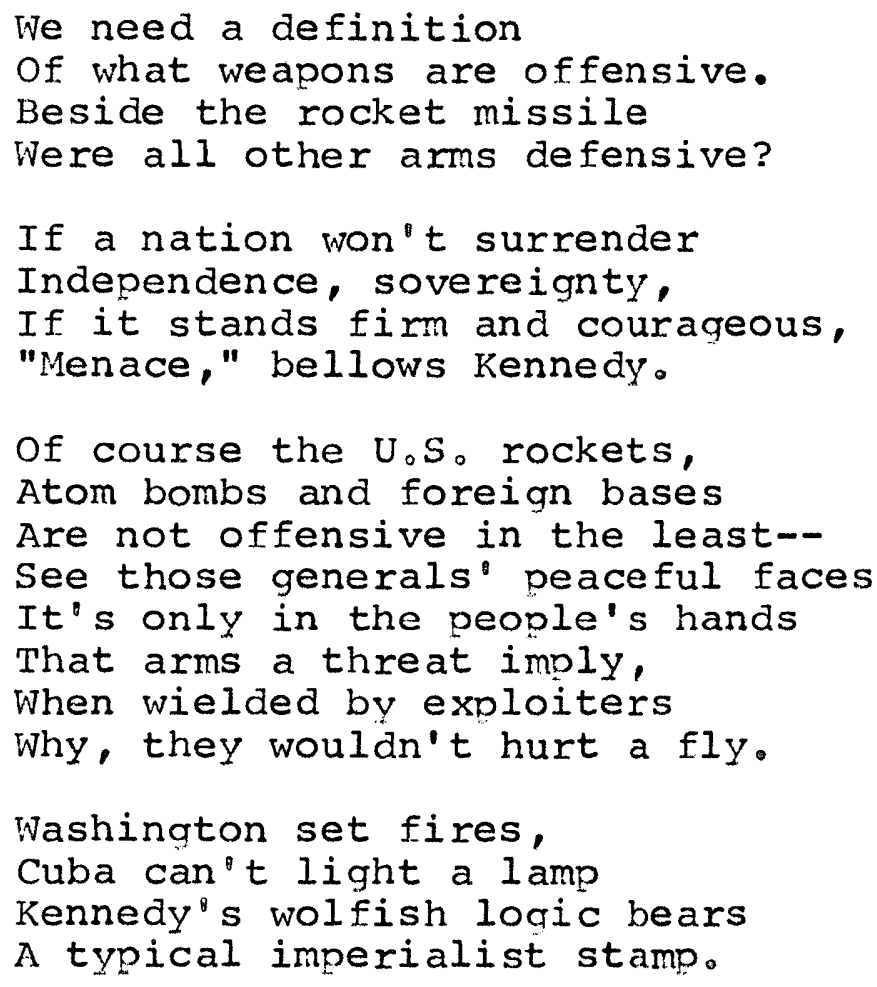

Often Communist poems with social themes offer us a rare opportunity to see the changina mores of the Chinese villagers. A good example is this popular poem "Sister-in-Law's Marriage." The poem was written in the form of a dialogue between a young woman and her 131. LOC. CIE. 
husband's young sister whose name is Hsiu-Chih. It tells how HsiuChih changed her mind about her former suitor san-suo, "a young farmer in her village who is wholehartedly devoted to socialism and puts all his energy into his work." 132

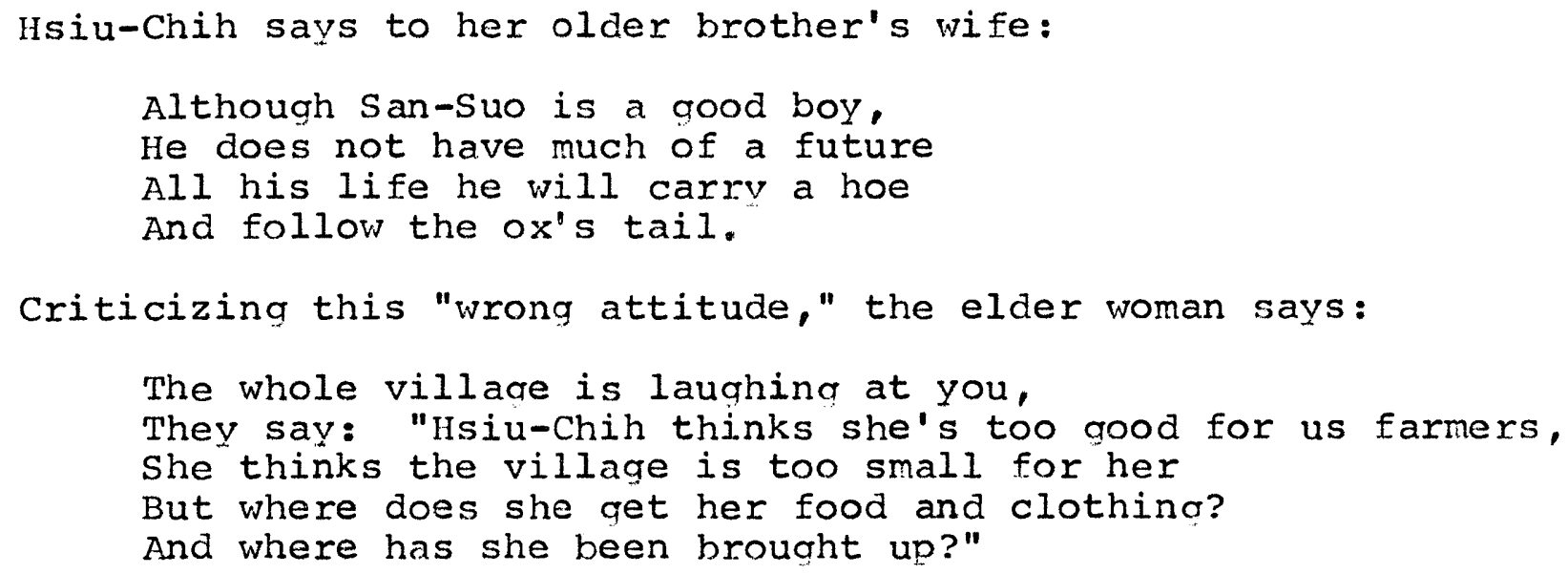

Then as the Communist report qoes, "Hsiu-Chih began to realize that she was wrong, and asks her sister-in-law to be the mediator and invite San-Suo over for a talk. As she leaves the older woman says half-jokingly:

You were the one who changed her mind But now perhaps he will drive a hard bargain.

It is reported that experiments have been made to increase the effectiveness of poetry-reading, such as using dialogue, choral reading or recitation to a musical accompaniment. The subjects of the poems are drawn from popular short stories, prose, plays and political speeches.

132. Yin Chin-kuang, op. cit., p. 29. 
VII

Conclusion

In concluding, let us attempt to evaluate the communist effort to transform the traditional media for purposes of modernization.

First, the traditional media were popular and influential among the people because they were a people's art. Thus, for example, in a 1926 social survey of north China sponsored by the Nationalist government, it was found that yang ke, a local song-anddance performance, was very popular among the peasants because ${ }^{133}$

They were a people's literature, developed by local groups. Traditional stories had been subject to local editing and changes. They were simple enough for all to understand, but with literary quality. They pictured life in the country as the country people would like to have it. Life as depicted on the stage represented high society for many of the villagers. Love making on the stage was certainly an emotional release for the crowd.

It might be added here that yang ke was among the first group of folk arts to be politicized by the Chinese Communists. It is now included in the category of Chuyi (tuneful art) that is given the new mission of depicting the Communist way of 1 ife and Communist doctrine.

The traditional media were influential because they satisfied the inner convictions of the peasantry. In the same 1926 survey, it was reported that 134

133. Sidney Do Gamble, Tina Hsien, New York, International Secretariat, Institute of Pacific Relations, 1954, p. 333. 134. Ibid。, p. 334。 
The people attending the plays combined worship

and recreation. Theatrical plays were often given, as a special offering, when the community was seeking help from the gods, asking for rain, or wanting protection from locusts or other pests and disasters. The plays given at the temple fairs were naturally related to the temple worship.

Second, the traditional media were effective because they crossed social barriers and appealed to all the people. They took place in a public location and were capable of reaching simultaneously a large number of diverse social nuclei。 The 1926 social survey reports that 135

The spectators were not limited to the inhabitants of the village qiving the plays, but came from the surrounding villages as well. It was an occasion for much local visiting and entertaining。

The Communist Chinese modernization effort hit hardest at the traditional media's strongest point, the fact that they were a people's art. The politicizing of theater, story-telling and ballad singing means that they are no longer a people ${ }^{\prime} s$ art but rather a Party's art. They now belong solely to the ruling class, the Communist Party. Structurally it is still an intermediary but substantively it is an instrument of the ruling elite.

Moreover, the revised traditional media do not satisfy the psychic need of the common people. One can agree with Peking that ghosts should not haunt the Chinese any longer. But to insist that these media carry politics and nothing but politics is to sever the media totally from the masses. Now any entertainment that has no politics in it is quickly withdrawn from the public. A foreign 135. LOC. CIE. 
correspondent in Peking told of how a successful circus was banned because "there was no value in it--no politics...."136

Nevertheless, the Party-controlled news media kept reporting wide popularity of the newly transformed entertainments. Then, oddly enough, in the midst of these reports, the Party's chief ideological organ, Hung Chi (Red Flag), reported that peasants resisted touring drama troupes and in some places peasants stoned the actors. The journal warned: 137

If there still are people who feel that all new plays do not have taste, then the responsibility does not lie with the new plays....

The stoning incident was disclosed in the Shanghai newspaper HsinMin Wan Pao (New Citizen Evening News). An editorial said that "bad elements" had stoned and driven away the drama company which was performing "Seizure of the official seal." The play, which was then being performed throughout the country, portrays the Party in a struggle with villainous rich peasants who take over a Communist production team. 138

It is not impossible to modernize traditional media. There are alternatives to letting old superstitious elements remain in the repertoire. On the contrary, the traditional media can be successfully modernized and constructive modern values can be skillfully introduced through them without eliminating their nature as people's

136. Jacques Marcuse, "Report (Limited) From Communist China," The New York Times Magazine, May 24, 1964, p. 108.

137. The New York Times, March 8, 1964.

138. LOC. Cit. 
art。 John J。 Gumperz observed such a feat in an Indian village: 139

There are several instances of performances in which the message differs considerably from the overt religious theme. In one performance a Doom actor inserted a long plea for Hindi-Muslim amity into the mythological story of $\mathrm{Nal}$ and Damayanti. Even as a government official, he would never have been accorded the attention he received nor the audience, had he attempted to make a prose speech.

Another instance is the Bhajan group, sponsored by the Arya Samaj sect of reform Hinduism, in which a single lecturer performs while accompanied by a group of musicians. The message of one of these lectures concerned fixed prices and honesty in business, a subject introduced in the guise of a story from the Upanishads. The lecturer started by telling of a sage who arrived at the home of a famous raja。 The raja paid him respect and offered him food, but the sage refused, saying, ${ }^{11}$ How do I know that your kingdom is not full of tightwads and profiteers?" The raja replied, "Sir, there are no sinners in my kingdom。 All goods in my kingdom are sold at fixed prices。" This last statement was repeated in song with musical accompaniment, using the Bhajan rag, a rag associated with devotional songs. The lecturer went on to tell how he met a sanyasi who had been in America who told him that goods are sold at fixed prices there and that Americans are so honest they leave money for their milk on their doorstep. This statement, accentuated by musical underscoring, was followed by a discussion on the need for more honesty in business dealing.

The intercaste audience listened to the lecture with seeming interest and several people later commented favourably on the honesty of Americans. This interest contrasts sharply with the reception accorded to a group of students from Merut who wrote a modern play dealina with village development. In spite of the fact that intermissions were filled with movie songs and other light entertainment, the attitude of the village audience remained negative and even hostile。 Many of them walked away before the end of the performance, criticizing the fact that the theme was from daily life and had no connection with mytholody.

139. John Jo Gumperz, "Reliqion and Social Communication in Village North India," The Journal of Asian Studies。 Vol。XXIII, June, 1964 , pp。95-96。 
This tale illustrates two things. The first is that the peasants' previous orientation toward supernatural beings cannot be changed overnight: modern plays that have no connection with this old orientation are rejected outright. We find a similar reaction on the part of the Chinese peasants toward the modern opera or revised traditional operas。 Second, the incorporation of modern values can be skillfully done even within the traditional orientation such as the introduction of fixed price notions into a religious play. But this approach the Chinese Communists have rejected outriaht。 Because of this rejection, Peking has severed the media from the people。 Instead of helping the peasants to adopt modern practices, peking has alienated them.

Gumperz also tells of how a traditional Arya Samaj singer used the Bhajan rag for songs about public health, the Japanese method for rice cultivation, etc。 "His activities have been singularly effective--he has been known to hold an audience of several hundred in bitter cold winter weather。"140 The important thing about this is that he was a good singer in the first place. Because of his professional skill, he was engaged by the Community Development Block in an Indian village. In contrast, we noted previously in this report that Peking usually turned out large numbers of story-tellers, singers and performers in a short period. Their professional skill cannot be expected to be high. Testimony to the public's reaction is that Peking had to organize people to listen to story-telling, as the following report reveals: 141

\section{I40. Ibid。}

141。 Kung-Jen Jih-Pao (Workers' Daily), March 24, 1964, p. 4. 
To insure a definite number of basic listeners, they (the storytellers) contact one or two units to make sure that a certain number of employees and workers will definitely come...

As of now the modernized traditional media in China have followed the same pattern of development as other media under the pekina regime. After rapid physical expansion they bogged down in unpopular products. By fanatical politicizing of every facet of chinese culture, Peking ended up in a worse state than before it started. Before, there were groups of professional actors, dramatists, playwrights, story-tellers and singers who had already established their reputation among the masses. These artists were overwhelmingly in support of the new regime, at least in the first few years. They were eager to serve the new government which, they thought, would bring a new and strong China. Instead of utilizing their talents for constructive purpose, Peking pulled the rug from under them. Their art was wrenched away from them by illiterate Party fanatics. And the masses were deprived of an entertainment which was once theirs. One American scholar commented that Peking has "lived off" of its social capital like "drunken sailors on a spree。" This is exactly what Peking did with its traditional media.

What, then, is the future course of the traditional media? The answer depends on the thinking of Mao Tse-tung and his few loyal followers. Leonard Schapiro comments that "the Soviet Communist Party, more than any other civiljan organization known to history, depends upon the personalities of those who rule from 
the top."142 The Chinese Communist party depends as much as the Soviet one on the personality of its leadership and, perhaps, even more. The whole nation is modelled on Mao Tse-tung and his old Yenan lieutenants. The fact that Mao is a sort of poet himself has made art and literature in Communist China suffer from this adulation more than any other field. With respect to technology, Mao has to consult technicians and engineers. But with respect to art and literature Mao feels no need to consult anyone because he considers himself highly qualified to give instructions. His talk on art and literature in Yenan in 1942 is the dogma that every literary worker must follow without deviation.

A man like Mao Tse-tung is not likely to change. His behavior corresponds to what Festinger and others have observed in a group of religious fanatics in Lake City, who refused to admit the reality that their prophecy of the last day of the world had failed to materialize. Festinger describes such behavior: ${ }^{143}$

A man with a conviction is a hard man to change. Tell him you disagree and he turns away. Show him facts or figures and he questions your sources. Appeal to logic and he fails to see your point. We are familiar with the variety of ingenious defenses ritl: which people protect their convictions, managing to keep them unscathed through the most devastating attacks。

But man's resourcefulness goes beyond simply protecting a belief. Suppose an individual believes something with his whole heart; suppose further that he has a commitment to this belief and that he has

142. Leonard Schapiro, The Communist Party of the soviet Union, guoted in Howard L. Boorman, "Iiu Shao-chi: A Political Profile," The China Quarterly, April-June, 1962, p. 1.

143. Leon Festinger, et aI." "When prophecy Fails," in Maccoby, et al. (ed.), Readings in Social Psycholoay, New York, Holt, Rinehart and winston, Inc。, 1958, p.156. 
taken irrevocable actions because of it; finally, suppose that he is presented with evidence, unequivocal and undeniable evidence, that his belief is wrong; what will happen? The individual will frequently emerge, not only unshaken, but even more convinced of the truth of his beliefs than ever before. Indeed, he may even show a new fervor for convincing and converting other people to his view.

In the history of the modernization of traditional Chinese media, nothing has disconfirmed Festinger's observation. The recurring waves of drama reform and present preoccupation with indoctrinating the youth all conform to Festinger's model. Peking's mayor Peng Chen's words at the 1964 Modern Peking Opera Festival were both propagandistic and predictive of the future course of the traditional media when he said that the communist "breeze" of reform "would stop blowing only if capitalism were restored and modern revisionists got into power in China." 144

144. See footnote No. 47. 


\section{Bibliography}

\section{Chinese Communist Publications: Chinese Text}

\section{Books}

Chen Erh-hun, Shou-Su Shaw-Shih (Short History of Story-Telling), Shanqhai, Chunq-Hua Book Store, 1936.

Chen Erh-hun, Shou-Su Shih-Hua (History of Story-Telling), Peking, Writer's Publishing Company, 1958.

Chu Su-chen, Kung-Chu Shih-Wu-Kuan (Kiangsu Opera Fifteen Strings of Cash), Hong Kong, San Lien Book Store, 1956.

Mao Tse-tung, Mao Tse-tung Hsun Chi (Selected Works of Mao Tsetunq), Peking, Vol. 3, 1961.

\section{Magazines}

Chao Chi-yang, "On the Reform of Drama and Sonq and Reform Dramatists' Thought," Wen-Yi Pao (Literary Gazette), Vol. 1, No. 11, 1950, p. 20 。

Hsin Yuan, "Some Problems on Rural Dramatic Troupes," Wen-Yi Pac. No. 2, 1952, p. 23.

Yang Kuanq, "The Differences in Rural Theatrical Troupes," Wen-Yi Pao, No. 24,1956, p. 31 .

Yi Pien, "The New Face of 'Fifteen Strinas of Cash," "Wen-Yi Pao, No. 9, 1956, p. 12. 
Communist Chinese Publications: English Text

Books

Anon., The Fisherman's Revenge, Peking, Foreion Lanquage Press, 1956.

Anon。, Ten Great Years, Peking, Foreign Lanquage Press, 1960.

Magazines

Chen Lin-jui, "A Popular Folk Drama," China Peconstructs, Pekina, No. $6,1952, p .23$.

Chou Yand, "New Folk Sonas Blaze a New Trail in Poetry," Chinese Literature, Peking, No. 5, 1958, p. 8 .

Fan Sui, "In a Szechuan Teahouse," China Reconstructs, Peking, No. $4,1964, \mathrm{p} .12$.

Li Hsia-yana, "Brino Opera to the Villade," China Reconstructs, No. $2,1961, \mathrm{p}, 18$.

Mei Lang-fang, "Old Art with a New Future," China Reconstructs, No. 5, 1952, p. 22 。

Shih Hwa-fu, "Old 3ards Sina New Themes," China Reconstructs, No. 2, 1959, p. 14.

Yin Chih-kuang, "Poetry Heard bv Millions," China Reconstructs, Peking, No. 8, 1963, p. 27.

Western Publications on China

Books

Brewitt-Taylor, C. H. (translator), San Kuo (Romance of the Three Kinacoms), Shanghai, Kelly \& Walsh, Ltd., 1925. 
Buck, Pearl S. (translator), All Men are Brothers (Shui Hu Chuan), New York, The John Day Company, 1933.

Buss, Kate, Studies in the Chinese Drama, New York, Jonathan Cape \& Harrison Smith, 1922.

Gamble, S. D., Ting Hsien: A North China Rural Community, New York, Institute of Pacific Relation, 1954.

Houn, Franklin, To Change a Nation, New York, The Free Press, 1961. Snow, Edgar, The Other Side of the River, New York, Random House, 1962.

Teng, Ssu-yu \& Fairbank, John K., China's Response to the West, New York, Atheneum Edition, 1963.

Zung, Cecillia S. L., Secrets of Chinese Drama, Shanghai, Kelly and Walsh, Ltd., 1937.

Periodicals

Anon., "The Socialist Singing Movement," Union Research Service, Hong Kong, Vol. 33, No. 25, December 24, 1963. Karnow, Stanley, "Why They Fled; Refugee Accounts," Current Scene, Hong Kong, Vol. 11, No. 22, October 15, 1963. 